\title{
Production and Circulation of Late Hellenistic Fine Table Ware in Central Dalmatia, Croatia
}

\author{
Maja Miše ${ }^{1,2}$, Patrick Quinn ${ }^{2}$, Michael Charlton ${ }^{2}$, Vincent Serneels ${ }^{1}$ and Alessandro \\ Montanari $^{3}$ \\ ${ }^{1}$ Department of Geosciences, University of Fribourg \\ ${ }^{2}$ UCL Institute of Archaeology. London \\ ${ }^{3}$ L'Osservatorio Geologico di Coldigioco, Ancona
}

\begin{abstract}
Detailed compositional analysis is used to assess the hypothesis that fine tableware were produced and distributed within Central Dalmatia (present day Croatia) during the Late Hellenistic period. Examples of Black Slipped and Grey Slipped Ware sherds from two Greek cities, Issa on the island of Vis and Pharos on the island of Hvar, both of which contain pottery kilns, were analysed via geochemistry and thin section petrography. These data were compared to raw material samples from both islands, fine table ware sherds from the Dalmatian harbour site of Siculi, today Resnik, and legacy chemical data from southern Italy and north-western Greece, based on their typological similarity, in order to shed light on their production locations and distribution. This novel approach to provenience studies of the Hellenistic fine tableware takes into account not only the local provenance of vessels, but tries to locate the place of manufacture of imported vessels and their possible imitations and development within the context of learning. Besides, authors argue that apart of movement of pottery, the raw material was transported via existing maritime routes and used by the two different workshops at the same time. In the amidst extensive Hellenistic trade networks, fine tableware have been produced in Central Dalmatia by emerging local centres in the Greek cities of Issa and Pharos.
\end{abstract}

Keywords: Fine tableware; Dalmatia; Late Hellenistic period; Geochemistry; Thin section petrography; Local production; Trade; Circulation

\section{Introduction}

The establishment of the Greek cities Issa on the island of Vis and Pharos on the island of Hvar on the Central Dalmatian islands at the beginning of the $4^{\text {th }} \mathrm{c} . \mathrm{BC}$ marked the beginning of social and economic change among the Iron Age communities of the East Adriatic (Figure 1). This is visible in the large quantities of Greek and Hellenistic pottery, the wine drinking sets, at indigenous settlements at this time (Miše 2015: 20-23, 2017 and 2019), as well as the wide circulation of amphorae in the Adriatic area (Kirigin 1994; Carre and Mattioli 2003; Kirigin et al. 2006; Šešelj 2009; Lahi 2009; Gamberini 2014; Carre et al. 2014; Miše et al. 2019). Previous studies have hypothesised that Issa and Pharos were key production sites of amphorae and Hellenistic fine tableware (Kirigin et al. 2002; Čargo and Miše 2010) and that Issa exported their products to settlements along the East Adriatic coast (Miše 2015: 40-41). In order to facilitate trade with indigenous communities further inland, it is believed that Issa established the harbour of Siculi, in present day Resnik, near Split. 


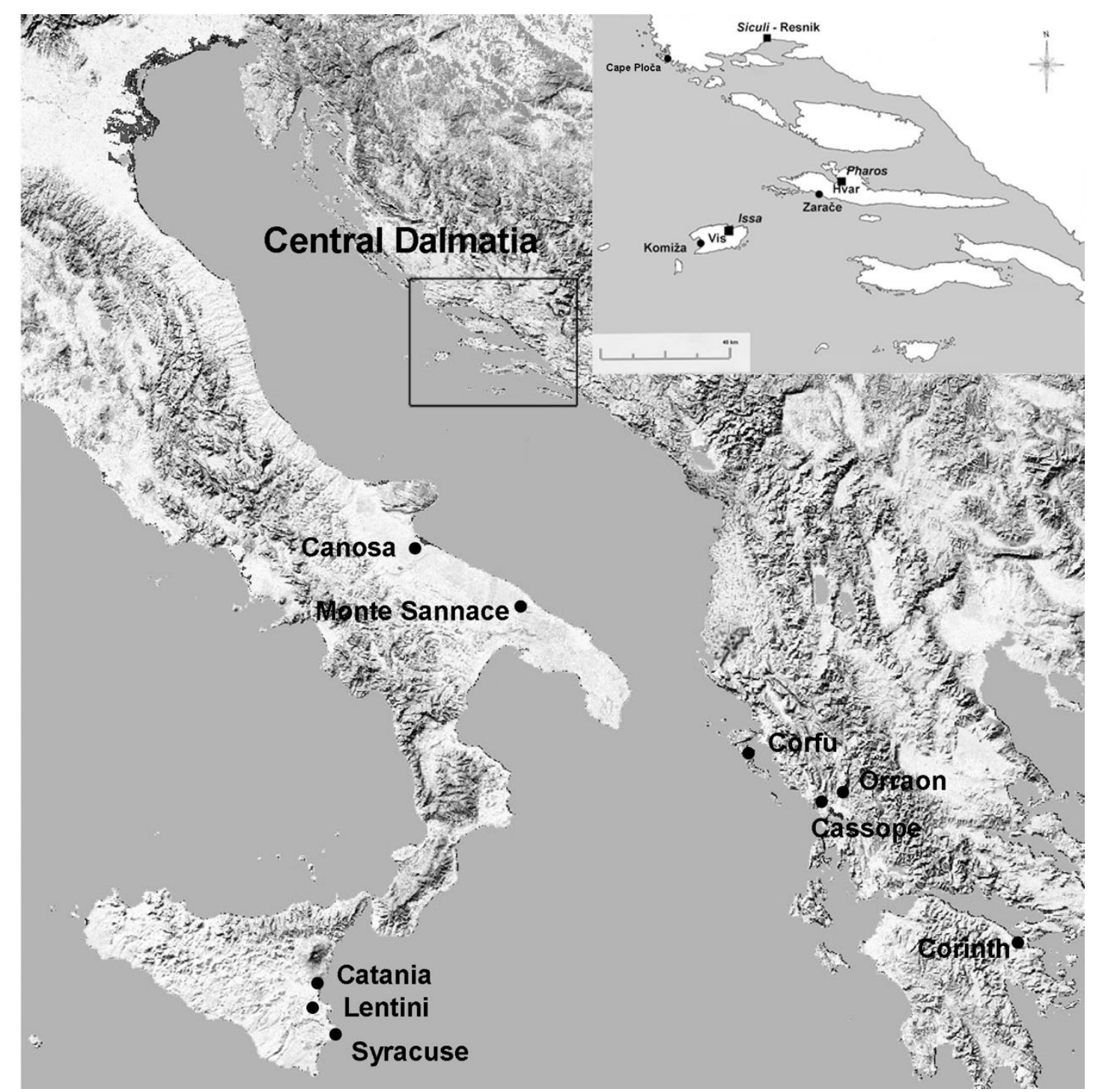

Figure 1. Map of Adriatic and Central Dalmatia with the location of Issa, Pharos, Siculi and the other geographic features and sites indicated in the text.

The abundance of Hellenistic fine tableware at Iron Age settlements signifies important cultural changes in the East Adriatic coast and poses key questions about pottery production, distribution and contacts that indigenous communities maintained with traders from Hellenistic city-states in the Adriatic-Ionian region. Rather than redistributing imported products from large Hellenistic production centres in southern Italy and Greece, Issa and Pharos may have established their own workshops and exported fine ware to communities along the eastern Adriatic coast and further inland. Whilst, subtle morphological and stylistic differences exist between southern Italian fine ware imports and local Dalmatian variants (Miše 2015: 30-40) (Figure 2), these are not always clear cut and distinguishing them among fragmented sherds is difficult (Figure 3). 


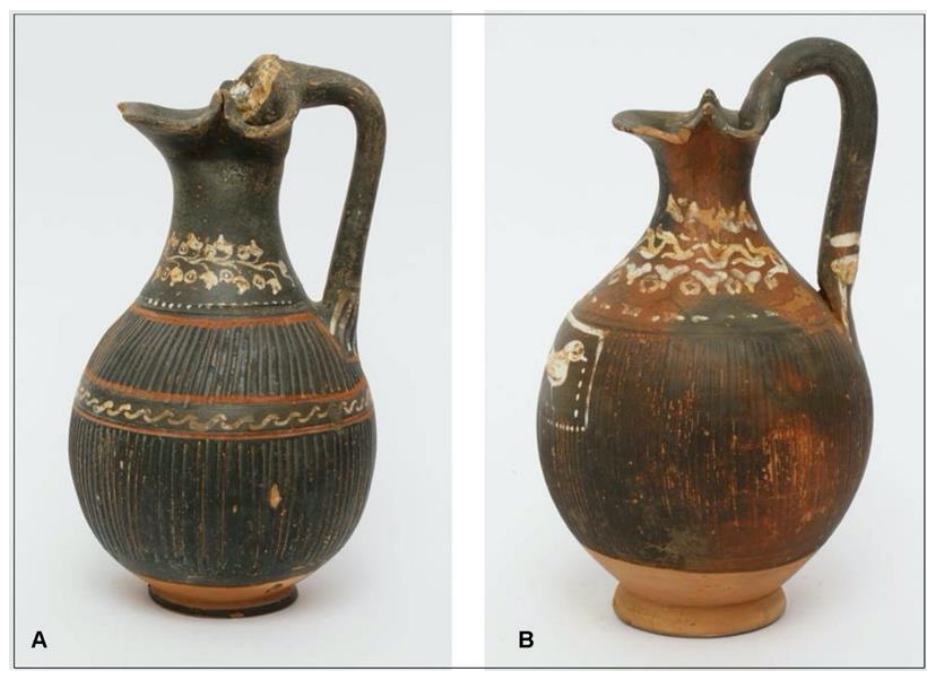

Figure 2. Images of Late Hellenistic fine ware from Issa. A. Typologically classified as import from southern Italy. B. Typologically classified as local Issaean ware (Archaeological Museum Split, Fb- 1699 (A) and Fb- 1032 (B))

In order to explore on the hypothesis that the Greek cities Issa and Pharos produced and exported fine ware pottery, the present study investigates the composition of examples of the most common Hellenistic fine tableware from both sites. Their petrographic and geochemical composition has been characterised in detail and compared to field samples of raw material from both islands, as well as sherds unearthed at the mainland harbour site of Siculi in Resnik. Finally, legacy compositional data on morphologically similar Hellenistic fine ware from South Italy, Sicily and north-western parts of Greece is used to assess the possibility that Issa and Pharos manufactured their own variants of this types of Hellenistic ware using local raw materials. The results of the study are discussed in terms of the nature of pottery production by Dalmatian Greeks and the existence of trade and cultural contacts with the Adriatic-Ionian region.

\section{Archaeological Background}

The Greek populations established an independent political and economic life, based on wine production and trade, upon their arrival in Central Dalmatia (Kirigin 1999, p. 147-164). It is believed that wine was cultivated on the Stari Grad Plain of Hvar (Figure 3A) (Slapšak and Kirigin 2001; Kirigin 2018) and on the Velo and Zlopoje Plains on the island of Vis (Figure 3B) (Kirigin et al. 2006). A key aspect of the culture of wine making and its consumption were ceramic drinking sets, including vessels such as pitchers (oinochoai) (Figure 2). This form, together with jugs (pelikai) and cups (skyphoi) are common in tombs at the Martvilo Necropolis in Issa, as well as the name 'Dionysus', the Greek God of wine, which commonly occurs on funeral stele (Kirigin 1985).

It is known that Issa and Pharos maintained trade contacts with southern Italy, particularly the port settlement of Canosa in northern Apulia (Šešelj 2009: 510-511), which was a major exporter of grain during the late $4^{\text {th }}$ and $3^{\text {rd }}$ c. BC (Figure 1). Typological classification and cross-examination of large quantities of the Hellenistic fine tableware from Greek and indigenous settlements along the East Adriatic coast reveal close correspondence with vessels from southern Italy, particularly decorated ware of the 'Gnathia' style. This suggests that these 
were imported for the purpose of wine drinking. Alternative hypotheses include that potters from Canosa settled on the islands of Vis and produce vessels in Issa with a similar style using local raw materials (Green 2001) or Dalmatian potters were inspired by southern Italian imported vessels to produce their own versions (Kirigin 1990; Miše 2013 and 2015: 40).

The discovery of pottery kilns at Issa and Pharos provides evidence to support the above suggestions. At Issa, part of a kiln was excavated in the late 1940s near the western Martvilo Necropolis, and possible remains of second kiln were found near the eastern Vlaška Njiva Necropolis. For the latter kiln, only written record from 1921 of its discovery was preserved (Čargo and Mise 2010). The remains of kiln were found during the recent excavations in the south-east corner of the residential complex at Pharos (Popović 2010; Popović and Devlahović 2018). Besides architectural remains of kilns, the debris of ceramic production in both Dalmatian Greek cities can be followed thorough unearthed moulds for Relief Hellenistic ware and lamps in Issa (Čargo and Miše 2010) and for terracotta figurines in Pharos (Popović 2010). Unfortunately, due to destructive nature of the applied compositional analysis in present study, the moulds were not analysed, and future analysis need to consider non-destructive methods, such as portable X-ray florescence, for their detailed compositional characterisation. Based on the assessments of the overall pottery assemblage through comparative typological observations of vessels and sherds from the south-eastern residential complex in Pharos (Kirigin, Hayes, Leech 2002) and compositional analysis of amphorae from Pharos (Miše et al. 2019) the kiln in Pharos has been operational from at least mid $4^{\text {th }} \mathrm{c}$. BC till the destruction of the town by Romans in the II Illyrian war in 219 BC. Typological and stylistically observations of sherds from the residential complex in Issa (Miše 2010) and of the published vessels from tombs at the Martvilo Necropolis (Miše 2013 and 2015), the local production in Issa started at the end of the $4^{\text {th }} \mathrm{c}$. BC and probably continued in Roman period. For the later date, we are still lacking detailed reports of Issa during the Roman period.

Excavations at Iron Age and Hellenistic sites along the Eastern Adriatic, such as the harbour of Siculi in Resnik (Figure 1), yielded large quantities of Hellenistic fine tableware. Šegvić et al. (2012) analysed samples from this site and interpreted them as being locally produced based on close geochemical correspondence between vessels of the same style. However, no kilns, wasters or other production remains have been reported from the site and no attempt was made to compare the ceramics to the local raw materials. It is therefore possible that this pottery was imported to Siculi, from either pottery workshops of Dalmatian Greek cities, or perhaps further afar. This assumption is also possible given the character of the site as a harbour and a distribution point.

\section{Materials and Methods}

\section{Material}

Forty-five Hellenistic fine tableware sherds were selected from the residential complex in Issa $(n=29)$ and from the south-eastern residential complex in Pharos $(n=16)$. These include sherds of wine drinking vessels of the well-known Black Slipped Ware (BSW) from Pharos, 
and both BSW and Grey Slipped Ware (GSW) from Issa (Table 1). Black Slipped Ware is sometimes referred to as 'Black Glazed Ware' due to the lustrous appearance of the slip. It was produced at various locations across the Mediterranean during the Classical and Hellenistic periods (Miše 2015: 55- 57). Grey Slipped Ware or simply 'Grey Ware' is also known as Campanian C for their first classification in this southern-Italian region (Morel 1981), and is still used as a synonym for other regional productions in Mediterranean. This type is characterised by a grey paste and grey coating achieved under reducing conditions during the final phase of firing and cooling (Mirti et al. 2001). It was manufactured from the $3^{\text {rd }}$ to late $2^{\text {nd }}$ centuries BC in several Mediterranean workshops (Morel 1981; Yntema 2001: 213 and 2005: 8-9) and is found in large numbers at many sites along the Eastern Adriatic coast (Miše 2015: 57-58). It is not however, common at Pharos.

The selected samples of the BSW can be dated in the $3^{\text {rd }} \mathrm{c}$. BC, while GSW to the $3^{\text {rd }}$ and $2^{\text {nd }}$ and RSW to $2^{\text {nd }} \mathrm{c}$. $\mathrm{BC}$, according to their style-typological analogies in the Adriatic - Ionian region (Miše 2015), and stratigraphic units in the recent excavations in Pharos (Popović 2010, Popović and Devlahović 2018). Based on the comparative style-typological criteria established by Miše (2015: 30-40) for identifying local imitations of southern Italian imports, the 11 sampled sherds from Issa and Pharos (VIS601, 603, 604, 605, 619, 622 and SGP602, 603, 629, 635, 636, and Table 1B and Figure 3C, E and F) could be classified as Italian imports, whereas the other 34 appear to be local variants (Table 1B, Figures 3A and B). Although, as abovementioned, the typological differences between imports and local products are difficult to determine on small sherds (Figure 3).

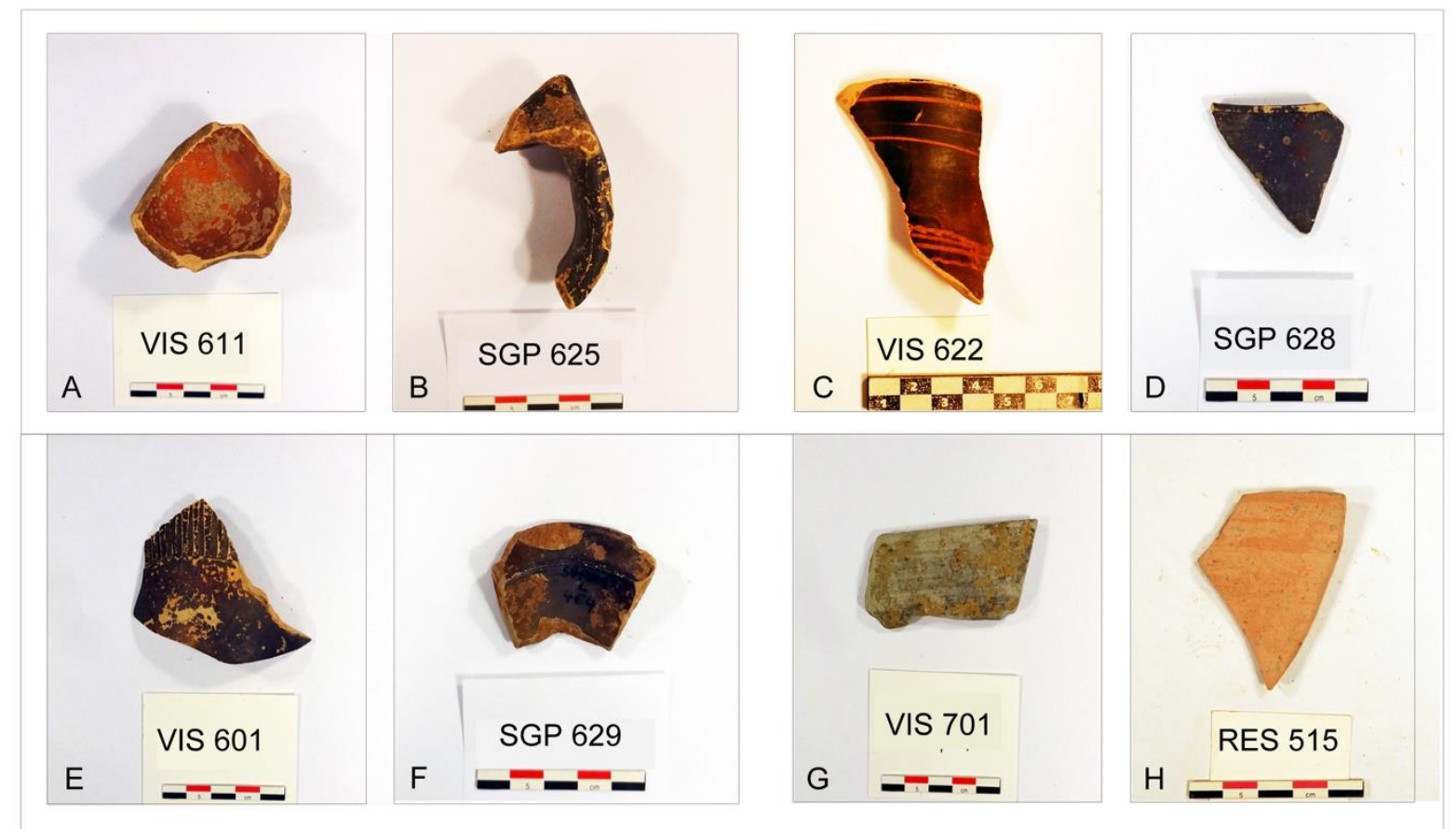

Figure 3. Selected images of analysed Late Hellenistic sherds from Issa (VIS), Pharos (SGP) and Siculi (RES). A) and B) BSW typologically classified as local imitations, C) to F) BSW typologically classified as southern Italian imports, G) BSW typologically classified as local and H) RSW from Siculi in Resnik 
Fifteen Hellenistic fine ware sherds were also sampled from harbour at Siculi, including BSW, GSW and Red Slipped Ware (RSW) (Figure 3H, Table 1A and B). The latter pottery type, which is particularly numerous at the site is morphologically related to Grey Slipped Ware. Several specimens were included in order to investigate this connection in more detail and shed light on their raw materials and production location.

\section{Wavelength dispersive X-ray florescence spectrometry}

All sherds were analysed using wavelength dispersive X-ray florescence spectrometry (WDXRF). They were abraded with a tungsten carbide drill bit to remove the slip coatings. Approximately $10 \mathrm{~g}$ of each sample was milled to a powder and loss on ignition was measured by thermogravimetry at $900^{\circ} \mathrm{C}$ using a LECO TGA 701. Samples were prepared as homogeneous glass tablets by melting them at $1050^{\circ} \mathrm{C}$ for $15 \mathrm{~min}$, inside a platinum crucible and mixing $0.7 \mathrm{~g}$ of ignited sample powder and $7 \mathrm{~g}$ of flux (6.65 $\mathrm{g}$ of MERCK Spectromelt A10 $\mathrm{Li}_{2} \mathrm{~B}_{4} \mathrm{O}_{7}$ and $0.35 \mathrm{~g}$ of MERCK LiF). The beads were analysed with a Philips PW 2400 WDS-XRF equipped with a Rhodium anode housed at the laboratory of the Department of Geosciences, University of Fribourg. The concentration of 22 major, minor and trace elements was calculated using an in-house calibration based on 40 international standards, mainly silicate rocks (Appendix 1). Data quality was assessed with an in-house clay reference sample, which indicated that all elements were measured with an accuracy of 5\% relative error or less (Appendix 2).

\section{Multivariable statistical analysis}

The multivariate geochemical data was examined via principal component analysis (PCA), average linkage hierarchical cluster analysis (HCA) and linear discriminant analysis (LDA) in order to characterise and compare the different wares from the three sites and identify geochemical groupings within the 60 analysed potsherds. All data was transformed to centred log-ratios (Aitchison 1986) prior to analysis to obtain freedom from the constant sum constraint.

\section{Ceramic petrography}

Based on their geochemical grouping, Chemical Group 1 and 2, as identified by the Principal Component Analysis (Figure 5), we selected 22 sherds of BSW and GSW from Issa and Pharos for detailed microstructural analysis by ceramic petrography. Within the ceramic thin sections, the main source of information are inclusions. Due to refined process of purification of raw material, fine ware pottery contains less inclusions and therefore less petrographic information than coarse ware (Quinn 2013: 7, 10). Although, less information can be recorded from the clay matrix and voids of fine ware (Quinn 2013: compare sections 4.1.3.1 to sections 4.1.3.2 and 4.1.3.3), we wanted to investigate whether geochemical groups differ in their microstructural composition as well.

All 22 selected samples were thin sectioned in a vertical orientation through the vessel wall of all sherds (Whitbread 1996: 415, Fig 1; Quinn 2013: 23-33) at the Department of Geoscience, University of Fribourg. These were examined under the polarising light microscope at the University of Fribourg and at the UCL Institute of Archaeology, at magnifications of x25-200 and studied in terms of composition, shape and texture of their particulate inclusions, the nature 
of their clay matrix and the shape, size and arrangement of voids. Attempts were made to group the thin sections into petrographic fabrics based on visual observation following the protocols in Whitbread (1995) and Quinn (2013).

\section{Geological prospecting}

In order to test whether the Hellenistic fine tableware sherds from Issa and Pharos were locally produced, a program of raw material prospection and analysis was carried out on the islands of Hvar and Vis. The geology of both Central Dalmatian islands, Vis and Hvar, is homogenous limestone (Figures 4A and B). This geological formation has karstic landscape with rare clay deposits. However, in the geological formation around Stari Grad Plain, the largest fertile field on the island of Hvar, and Velo Polje, the largest field on the island of Vis, formation of terra rossa soils can be in situ or derived from the karstic dissolution of a limestone bedrock. Using geological maps and accompanying reports (Korbar et al. 2012; Oštrić et al. 2015), as well as information provided by interviews with local people, attempts were made to identify and sample deposits in the area that could have been used as a source of raw material for ceramic production in the past (Table 2).

On the island of Hvar, a total of 7 samples of terra rossa soil were collected around ancient Pharos and 2 samples of terra rossa soils in the Stari Grad Plain. The 2 samples of Eocene flysch clay deposits were collected in Zarače Bay on the southern coast of the island of Hvar (Figure 4A). On the Vis island a total of 22 samples of terra rossa soils formed in limestone were collected around ancient Issa and clayey material that formed over pyroclastic rocks above Komiža Bay, on southern side of the island, identified by Šegvić et al. (2012) as possible source of raw material for the Hellenistic pottery production in Issa (Figure 4B). During the extensive geological mapping of the island of Vis, Eocene flysch clay was not geologically recorded on the island (pers. comm. with T. Korbar from Croatian Geological Survey). Due to extensive modern developments in the surrounding area of ancient Issa and Pharos, it was not possible to access all deposits that were also, due to overgrown vegetation, not easy to find.

All collected raw material samples were refined in the laboratory by settling and sieved with diameter of $1 \mathrm{~mm}$. The refined clay fraction was then formed into briquettes and fired at the $850^{\circ} \mathrm{C}$ in an electric kiln under oxidising conditions (following description for the paste preparation and firing temperature for the Greek and Hellenistic fine ware production in Cuomo di Caprio 2007: 150-151). However, not all collected samples of terra rossa soil were suitable for modelling briquettes, they were either too dry and lack of plasticity for modelling briquettes. This is also confirmed for the clayey material from Komiža bay on Vis. Subsequently, 7 samples of terra rossa soil from Vis, and 2 samples of the terra rossa from Hvar together with 2 samples of Eocene flysch clay were fired in briquettes, and were thin sectioned and characterised geochemically (Table 2) in the same manner as the archaeological ceramics, described above. Although, clayey material from Komiža bay was not suitable for briquettes, they were chemically characterised due to above-mentioned assumption as being a source of raw material in ancient production. The raw material thin sections were compared to the fine ware sherds under the microscope. A LDA model was created for observed sherds and added to clays to identify potential matching. 


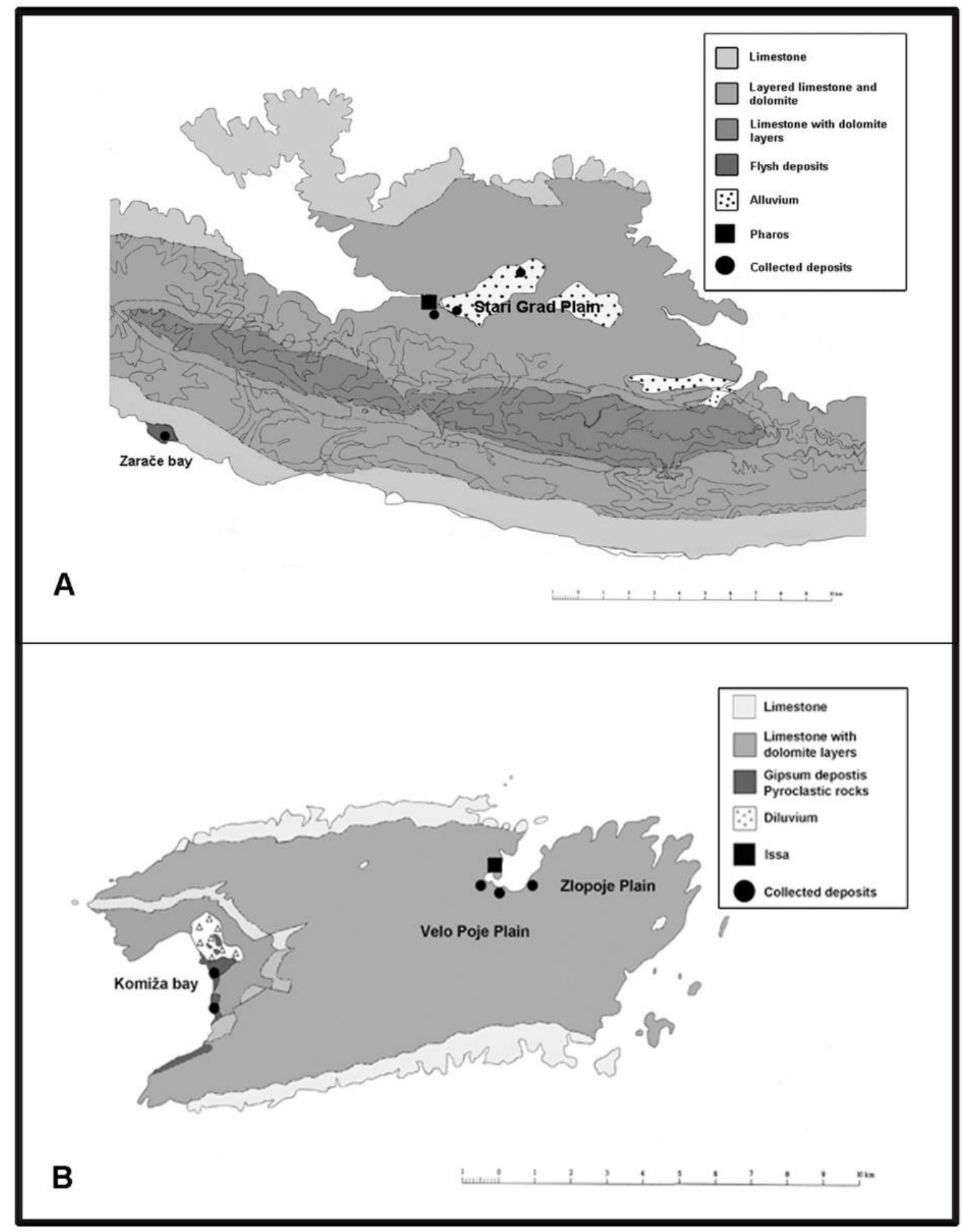

Figure 4. Map indicating location of raw material field samples collected from the islands of Hvar (A) and Vis (B), including simplified bedrock geology. Based on Ořtrić et al. (2015) and Korbar et al. (2012) respectively.

Comparison by legacy data

Although, the Hellenistic fine ware imports analysed in the present study are identify base on the style-typological observations, the published data on morphologically identical sherds from South Italy, Sicily, the Ionian, Peloponnese and Epirus regions of Greece was utilised to verify their non-local origin (Farnsworth et al. 1977; Rotunno et al. 1997; Barone et al. 2005, 2014; Papachristodoulou et al. 2006, 2010; Mangone et al. 2008). By comparing the geochemical characteristics of the sherds from Issa, Pharos and Siculi with these published datasets it was possible to test the possibility that they originated from outside the Dalmatian and Adriatic 
regions. Although, a direct statistical classification cannot be attempted with published datasets due to different approaches and apparatus used, general comparisons were made on the values of certain elements. It has been suggested that values of $\mathrm{Cr}$ and $\mathrm{Ni}$ can be used to distinguish between Hellenistic ware thought to have been produced in southern Italy and north-western Greece (Farnsworth et al. 1977; Jones 1986; Barone et al. 2005). The values of these two elements were compared in two-variable scatterplots in order to visualise differences and similarities between Dalmatian Hellenistic ware and the legacy data from above-mentioned regions.

\section{Results}

\section{Geochemical analysis by XRF}

The concentration of the 22 measured elements was summed for each of the 60 analysed fine ware samples (Table 1A) and one sherd of BSW from Issa (VIS619), which had a low total $(89.96 \%)$ was omitted. Two elements exhibited very high variation between samples, the $\mathrm{CaO}$ (32\%) and $\mathrm{Pb} 2 \mathrm{O} 5$ (94\%) and they were also removed for the dataset. The latter can be affected during the burial of ceramics (Freestone 2001), while values of the $\mathrm{CaO}$ in RSW samples, with standard deviation of $18 \%$ (Table 1A), were outside of the detection limit of the WD-XRF (Appendix 1). Besides the high variability of $\mathrm{CaO}$ between ceramic samples, the variably of $\mathrm{CaO}$ values is even greater between the raw material and analysed sherds (Table 1 and $1 \mathrm{~A}$ ), that can constraint their direct comparison and $\mathrm{CaO}$ was removed from further analysis. The values for the 19 elements (Al, Ba, Cr, Cu, Fe, K, Mg, Mn, Na, Nb, Ni, Rb, Si, Sr, Ti, V, Y, $\mathrm{Zn}$ and $\mathrm{Zr}$ ) were examined to identify obvious geochemical patterning in the dataset, before commencing multivariate statistics.

A plot of principal components 1 and 2 (Figure 5A), which explain 65\% of the total variance in the dataset, reveals the presence of three main groups. The largest of these, the Chemical Group 1, is characterised by high Mg and $\mathrm{Ni}$ (Figure 5B; Table 1A) and consists of the majority of the BSW sherds and all of the GSW samples, but none the RSW samples. By conducting PCA on the samples from Chemical Group 1 only (Figure 5C, D) it can be seen that significant overlap exists between the composition of the sherds of the same ware group collected from different sites, as well as different wares collected from the same and different sites. Chemical Group 1 contains five of the eleven BSW sherds that were suspected to have been imported from southern Italy based on their shape and decoration. These do not differ chemically from possible local products. A second more dispersed chemical group, the Chemical Group 2, is composed of six BSW sherds from Issa and Pharos, all suspected imports, which have lower $\mathrm{Cr}, \mathrm{Ni}$ and $\mathrm{Ti}$ than the other fine ware samples, including the other $32 \mathrm{BSW}$ sherds (Figures 5A; Table 1). Finally, a third group, the Chemical Group 3, consists of all five RSW sherds from the port of Siculi, which have high $\mathrm{Ca}$, Si and Z, low Al, K and Mn (Figures 5A; Table 1A). The same three compositional groups were also detected within the dataset via average linkage hierarchical cluster analysis (Figure 6). 


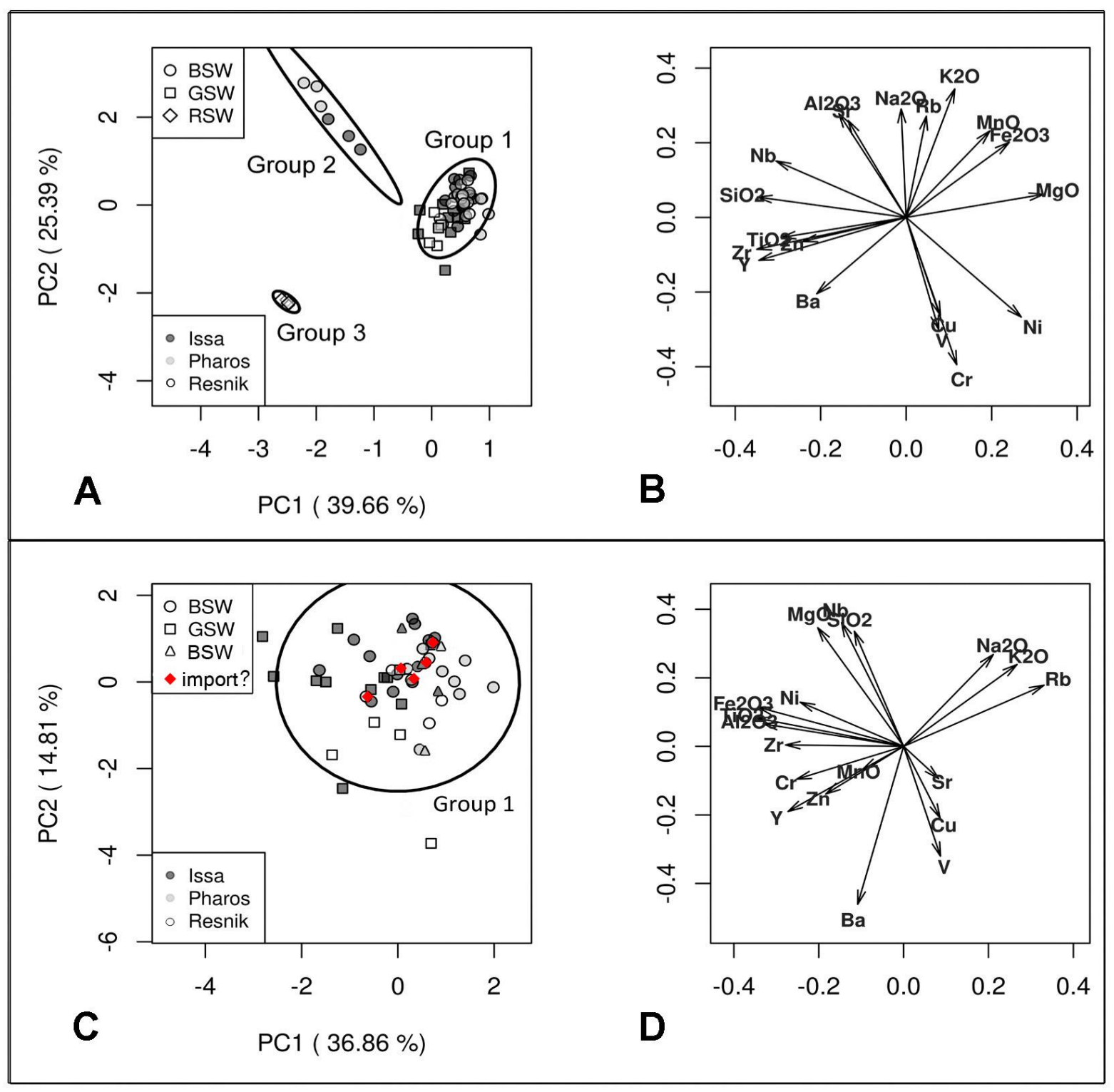

Figure 5. Principal components analysis of geochemical data on 18 elements within 59 Late Hellenistic fine ware ceramics from Issa, Pharos, Siculi

A. Scatterplot of principal components 1 and 2 from PCA on full dataset, labelled according to site and ware group and indicating the presence of three groups. B. Loading plot for the above, indicating the influence of 18 elements in the PCA. C. Scatterplot of principal components 1 and 2 from PCA of Group 1 samples only, labelled on group according to site and ware group, and those marked red are typologically classified as imports. D. Loading plot for the above indicating the influence of 18 elements in the PCA 


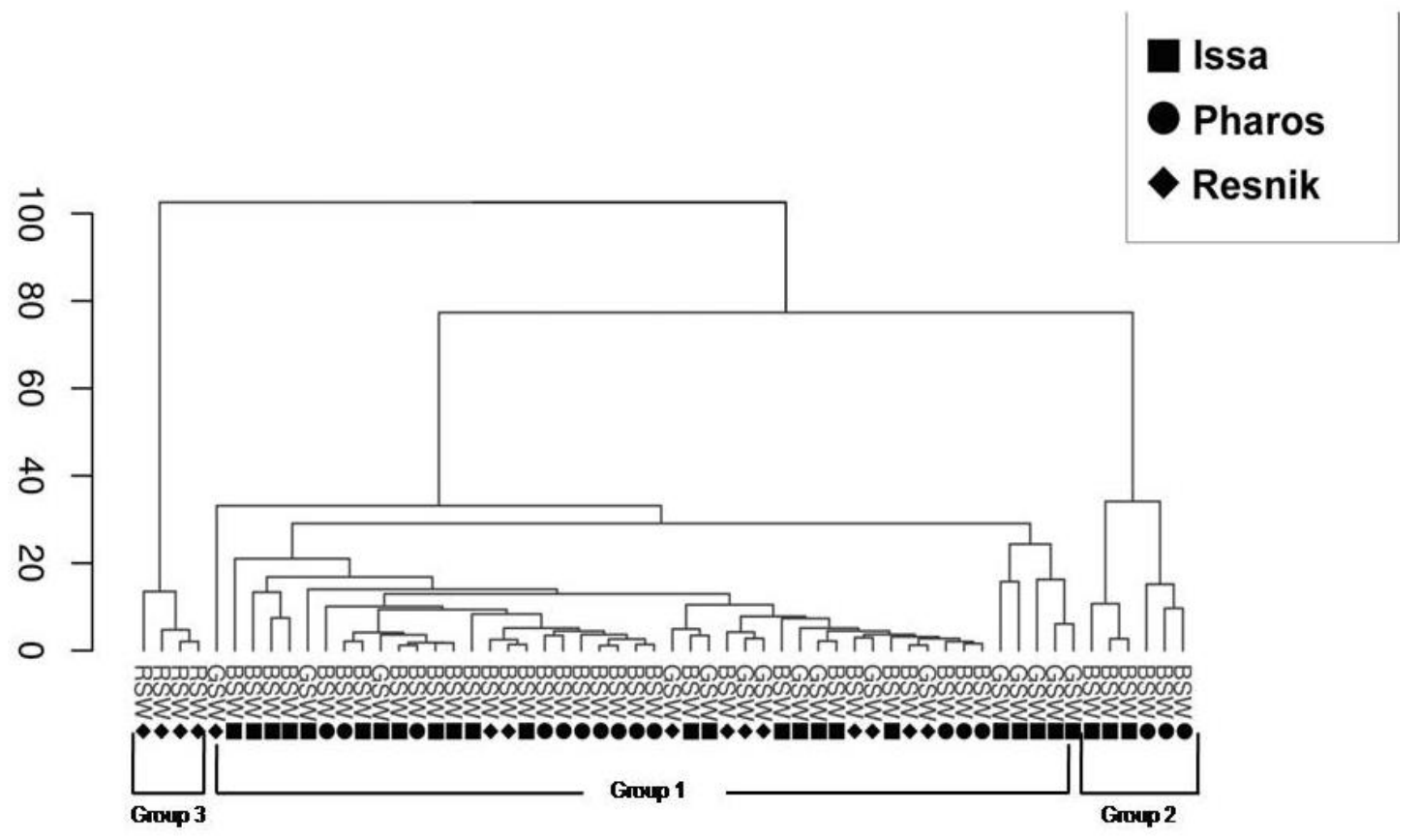

Figure 6. Hierarchical cluster analysis of geochemical data on 18 elements within Late Hellenistic fine ware ceramics from Issa, Pharos, Siculi (presented in the dendogram as Resnik). Leaves of dendrogram are labelled according to site and ware group.

The 15 processed raw material samples were found to be suitably for modelling briquettes, except two specimens from Komiža Bay on Vis. Clay from Komiža bay also have very different chemical composition from analyses samples (Table 2), and it is unlikely source of raw material for their production. After excluding these, as well as one sample of terra rossa soil (VISTR9), which had a low analytical total, data on the remaining 11 raw materials were subjected to linear discriminant analysis (LDA) along with the 59 fine ware sherds, in order to detect geochemical matches between the two datasets (Figure 7). This reveals that Eocene Flysch clay from Hvar (samples FL1 and FL2) is similar to the Chemical Group 1 and three terra rossa soil samples from Vis (VISTR8, VISTR23 and VISTR24B) plot close to the Chemical Group 2. The RSW sherds from Siculi that constitute Chemical Group 3, are not related to any of the raw material samples collected from the two islands. 


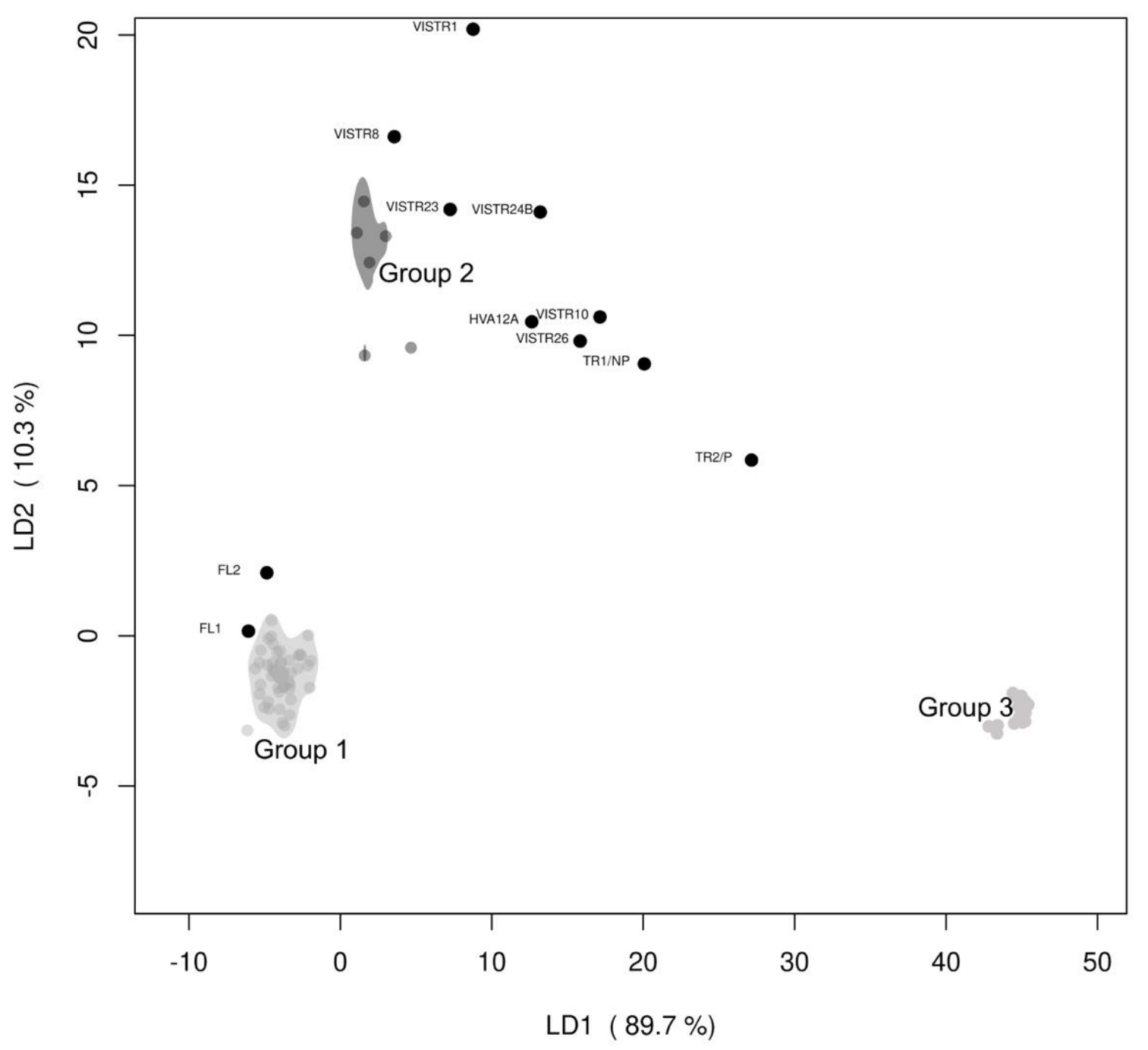

Figure 7. Linear discriminant analysis scatterplot comparing geochemically the three compositional groups detected by PCA within 59 Late Hellenistic fine ware ceramics from Issa, Pharos, Siculi with 11 clay samples collected on the islands of Hvar and Vis.

\section{Ceramic petrography}

Based on compositional grouping of BSW and GSW sherds in Chemical Group 1 and 2, as shown in Figure 5A, we wanted to see if the sherds differ in their fabrics, as well as in their chemical composition. The ceramic petrographic analysis was conducted on 22 sherds of BSW and GSW from Issa, Pharos and Siculi in Resnik (Table 1B). As mentioned above, the fine ware pottery contains less petrographic information than coarse ware (Quinn 2013: 7, 10), due to purification in the paste preparation process and contain less inclusions, who are the main source of information within ceramic thin sections. Although all samples have similar fabrics, with detailed petrographic descriptions, some small differences in the fabrics can be identified and divided into 3 petrographic groups.

Petrographic Group 1 (VIS605, VIS607, VIS610, VIS618, VIS620, SGP611, SGP614, SGP616, SGP619, SGP622, SGP626, SGP638 and SGP639) belonging to BSW, is 
characterised with non-calcareous, homogenous reddish matrix with low optical activity and estimated abundance of inclusions of $30 \%$. All inclusions are well sorted, closed spaced, very fine silt-sized $(0.08-0.16 \mathrm{~mm})$ and sub-rounded and rounded in shape. (Figure 8, 1A and B). Predominant inclusions are quartz monocrystalline. Clay pallets are common, and calcite, biotite mice and plagioclase feldspar are rare. No other inclusions could be identified. Voids are also rare, vughs in shape and less than $1 \mathrm{~mm}$ in size. Petrographic Group 1 corresponds to the Chemical Group 1.

Petrographic Group 2 (VIS701, VIS703, VIS704, VIS705 and VIS706) belonging to the GSW (Figure 8, 2A and B). This group has the same fabric description as previous Petrographic Group 1, but with grey homogenous matrix. This group also corresponds to the Chemical Group 1.

Petrographic Group 3 (VIS601, VIS603, SGP602 and SGP603) belong to the BSW, is characterised with non-calcareous and homogenous reddish matrix with low optical activity and estimated abundance of inclusions 50\%. All inclusions are well sorted, closed spaced, very fine silt-sized $(0.08-0.16 \mathrm{~mm})$ and sub-rounded and rounded in shape (Figure 8, 3A and B). Predominant inclusions are quartz monocrystalline. Clay pallets are common, while calcite, biotite mice and plagioclase feldspar are rare. Voids are also common and are vughs in shape and less than $1 \mathrm{~mm}$ in size. Petrographic Group 3 corresponds to the Chemical Group 2

No petrographic distinction was detected between the Petrographic Group 1 and 2, that is between BSW and GSW sherds in thin section, except for the colour of their clay matrices, which is likely to be due to different firing conditions. The BSW samples in Petrographic Group 3, belonging to Chemical Group 2, differ from those belonging to Petrographic Group 1 only in terms of the abundance of the inclusions in the clay matrix, that may suggest different paste preparation. The fine clay matrix with no large or rounded and angular inclusions may suggest that the clay paste used to manufacture the ceramics could have been refined by settling or levigation (Whitbread 1995: 392; Quinn 2013: 154-156).

A petrographic comparison between the pottery thin sections and those made from the fired clay briquettes revealed that few matches exist. The Eocene flysch clay samples from Zarače Bay, Hvar that were found to be chemically related to the BSW and GSW of Chemical Group 1 (Figure 7) are characterised in thin section by clasts of limestone, silt-sized quartz and very fine sand-sized foraminifera microfossils (Figure 8,4A and B). 


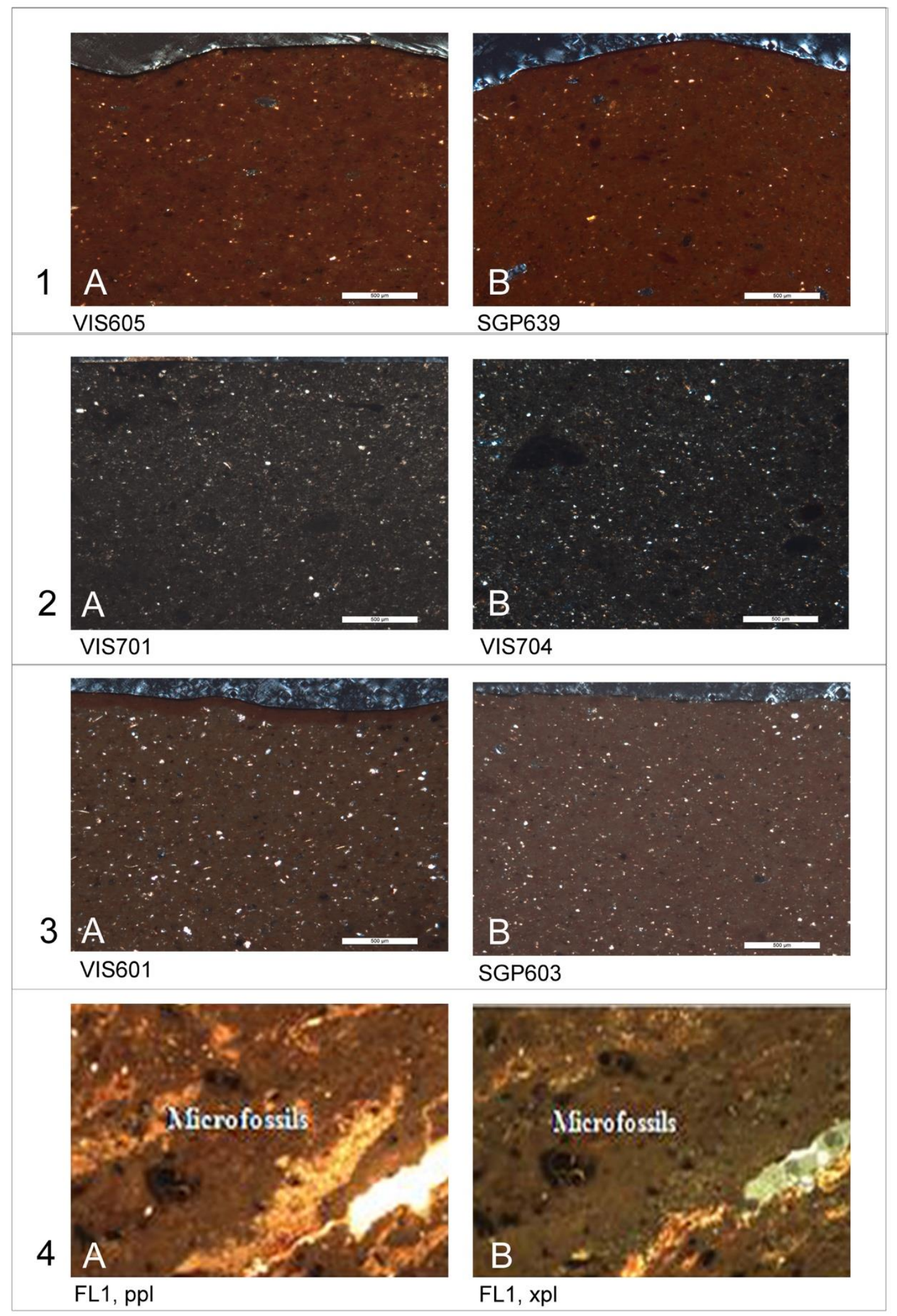

Figure 8. Thin section photomicrographs of Late Hellenistic fine ware ceramics from Issa, Pharos, Siculi and raw material field samples collected from the islands of Hvar. A) BSW from Issa and Pharos classified in Petrographic Group 1 B) BSW from Issa and Pharos classified in Petrographic Group 2. C) GSW from Issa classified in Petrographic Group 3. 
D) Fired briquette of the Eocene flysch clay sample from Zarače Bay, Hvar. All magnification on the microphotographs are $500 \mu \mathrm{m}$

\section{Discussion}

\section{Compositional relationship between different type of Hellenistic fine tableware}

The overlap between the BSW and GSW sherds in the Chemical Group 1 (Figure 5A, C) indicates that pottery of these two related types have a similar composition. Sherds of both types of wares excavated from Issa are chemically indistinguishable from one another, as well as from BSW type from Pharos and Siculi. This suggests that the samples in the Chemical Group 1, the majority of the ceramics analysed in this study, were made with the same raw materials and paste preparation process. This interpretation is also suggested by the petrographic characteristics of the thin sectioned sherds. The BSW and GSW sherds in Petrographic Group 1 and 2 have the same types of inclusions, and only differ in the colour of matrices, suggesting different firing temperature of the paste prepared with the same recipe. With this in mind, it is likely that they were manufactured by a single workshop or workshops in the same geological context that share the same clayey raw material and preparations methods, rather than being the products of several geographically separate regional centres. This seems to be confer with the morphological features of the samples in this group, that are thought to be local variation of the southern Italian products.

The presence, within Chemical Group 1, of five sherds of BSW (VIS605, VIS619, VIS625, SGP635 and SGP636) that are based on their typological classification, suspected to have been made in southern Italy, raises doubts about the morphological distinction between imports and possible local vessels (Figure 5C). It is unlikely, given geological variations of the Dalmatian and southern Italian regions, that pottery could be so closely related compositionally. The Dalmatian islands, as mentioned before, are homogenous limestone, while the southern Italian region is more geologically diverse with more pottery workshops in different geological areas (for more about geological areas surrounding identified southern Italian workshops see for Apulia Rotunno et al. 1997 and Mangone et al. 2008, and for Calabria and Sicily Barone et al. 2005, 2014). A more likely scenario is that the BSW sherds in Chemical Group 1 were produced by a single workshop using the same raw materials and that the typological differences between the sherds can be explained in other ways, for example in terms of the products of several potters within a workshop, each with their own distinct style due to the cultural context of learning or by copying error. The latter is an unintended and universal phenomenon as result of human perceptual-motor limitations that prevent the potter from a perfect replication of a given model, even if the potter is an expert (Gandon et al. 2014a). In fact, the subtitle morphological differences of standardise shapes of BSW in the Chemical Group 1, can be better explained by the constrains of the cultural context into which learning takes place and therefore to be a source of predictable variation (Lemonnier 1986; Gosselain 2000; Gandon et al. 2014a) and/or by introduction of novelty into standardise forms (Costin 1991 and 2000; Gandon et al. 2014b). In other words, variations between vessels of the same type, in this case between BSW in Chemical group 1, can be expected within the same workshop and these should not be considered as new types of ware, but as developments within the BSW in cultural context of learning. On the other hand, the same composition of BSW and 
GSW in the Chemical Group 1 could be observed as objects which have evolved from the same cultural context, but independently from multiple chains of transmissions (Gandon et al. 2014a). BSW and GSW, although belong to different types of ware, as defined by different colour of coatings, have the similar shape. In this case the potters used the same raw material and paste preparation process for modelling the same shape, but they deliberately chose different firing process. The fact that these two types of ware belong to the same chemical group strengthens the argument that one workshop could produce different types of fine ware during the Late Hellenistic period.

The six sherds of BSW that make up the Chemical Group 2 are compositionally different from those of the Chemical Group 1 in terms of their elemental and petrographic characteristics. This does not appear to be the result of alteration in the burial environment, as that they were excavated from both Issa and Pharos. It is therefore likely that these six sherds were made using different raw materials and paste preparation methods to those of Chemical Group 1, and most probably by a separate workshop. Though the BSW sherds from the two sites in Chemical Group 2 are not overlapping, they plot very close to one another (Figure 5A) indicating that they may have a similar origin. All six samples exhibit some morphological features that could suggest that they are southern Italian imports. Comparing them to the legacy data, as explain below, confirmed this hypothesis.

Turning to the Chemical Group 3, which consists of the five RSW sherds, all unearthed in Siculi in Resnik. These samples have distinctive composition that differs significantly from the sherds of Chemical Groups 1 and 2. They are likely to have been produced with different raw materials to the other 54 sherds. It is possible to rule out post-depositional alteration due to their chemical distinction from the BSW and GSW samples also analysed from Siculi. With this in mind, their unique composition with the present dataset indicates that RSW is not directly connected with these other Hellenistic fine ware types, BSW and GSW, and are produced by a different workshop. Certainly, no connection can be proposed between this pottery type and either BSW or GSW from Issa or Pharos and further analysis is needed to clarify the origin of the RSW from Siculi.

\section{Source of production}

Disregarding the potentially misleading typological differences between the suspected imports and local variants and focussing on the compositional data only, within present dataset there are three chemically distinctive groups of fine ware sherds. Sherds of Chemical Group 1 are present at Issa, Pharos and Siculi, Chemical Group 2 sherds occur at Issa and Pharos and Chemical Group 3 ceramics only at Siculi, among the 59 samples analysed. Having established this, the next question is where these ceramic compositional groups were produced. The geochemical and petrographic comparisons between the ceramics and the raw material collected and analysed from the islands of Vis and Hvar can be used to shed light on the possibility that one or more compositional groups of sherds were made at Issa or Pharos. The match between Chemical Group 1 and the Eocene flysch clay samples from Zarače Bay, Hvar, could suggest that this was the source of raw material for production of these ceramics. The absence of microfossils in the ceramics and their presence in the Eocene flysch clays, as seen in the thin sections (Figure 8, 4A and B), can be explained by a process of refining of the raw 
material and firing temperature which could remove these silt-sized bioclasts (Quinn 2013: 154-156). The presence of chemically similar BSW sherds at Issa would then have to be explained either by the movement of fine ware between two islands, that is between Issa and Pharos, or that they both shared the same source of raw material and the paste preparation recipe. The latter will include the transport of flysch clay from Zarače bay to Issa (since this type of clay has not been recorded in the geology of Vis island) and to Pharos. Zarače bay is located on the southern part of the island of Hvar with a mountain range between the bay and the ancient city of Pharos. Issa, situated on the northern side of the island of Vis, had better access to this source trough maritime transport that was more affordable (Horden and Purcell 2000: 11). It is true that pottery workshops were typically located close to sources of bulky raw materials such as clay, temper, fuel and water (e.g. Arnold 1985: 32-60). On the other hand, Zarače bay lays on the maritime trade route between both cities, Issa and Pharos, so the transport of this raw material to the both workshops is possible. A long-distance transport of raw material for ceramic production in not unusual. The discovery of the imported clay in amphorae in the Tell al-Timai, ancient Thmuis in the central Nile delta, that matches the chemical composition of fired vessels in the kiln of the $4^{\text {th }}$ c. BC (Hudson et al. 2018), straighten the possibility of raw material transport in Central Dalmatia during the Hellenistic period.

The broad correspondence between three samples of terra rossa soils collected from Vis with the sherds of Chemical Group 2 could also be indicative of their production at Issa, though the compositional match is less convincing in this case.

Analysed sherds of BSW belong to two different chemical groups, Group 1 and 2. This may suggest that this type of ware was produced with two different types of raw materials at one or more workshops. Though they production in the same workshop with different raw material is not impossible, it seems unlikely. A better explanation would be that one of the chemically distinct groups of BSW, samples in the Chemical Group 2, were imported. This argument can be strengthened with their different chemical composition compared to the raw material from Zarače bay.

The lack of correspondence between the raw material samples from Vis and Hvar and the five RSW sherds from Siculi in Resnik seems to rule out the possibility that this group was manufactured at either site and was imported to the mainland harbour site from different workshop.

\section{Regional differences and possible imports}

The movement of pottery has been main source of identifying trade and exchange systems among the ancient communities. The increase of trade towards the Late Hellenistic and Roman Republican period (Parker 1992), increased the movement of fine tableware. In order to seek possible non-local origin for analysed Hellenistic fine ware from Issa, Pharos and Siculi in this study, and trace possible imports from other workshops and regions, comparisons were made with published geochemical data on stylistically similar material from southern Italy and Sicily (Rotunno et al. 1997; Barone et al. 2005, 2014; Mangone et al. 2008), and north-western Greece (Farnsworth et al. 1977; Papachristodoulou et al. 2006 and 2010). The latter region was 
chosen based on the typological similarities between RSW from Siculi and from Ambrakia in

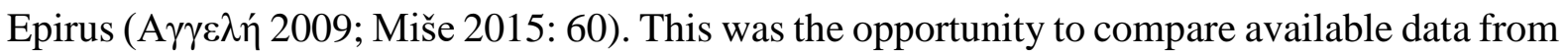
north-western part of Greece to our RSW samples in order to shed a light on their possible origin outside Adriatic basin.

Direct statistical classification cannot be attempted with published datasets due to the different approaches and apparatus used. However, general comparisons can be made in terms of certain elements. As mentioned above, it has been suggested that values of $\mathrm{Cr}$ and $\mathrm{Ni}$ can be used to distinguish between Hellenistic ware thought to have been produced in southern Italy and north-western Greece (Farnsworth et al. 1977; Jones 1986; Barone et al. 2005). Concentrations of $\mathrm{Ni}$ and $\mathrm{Cr}$ in southern Italy is lower $(<150 \mathrm{ppm})$ than in samples from Greece (> $200 \mathrm{ppm})$. For the latter region, the chemical composition of the raw materials seems to be influenced by the outcropping of ophiolite nappe (Barone et al. 2011). By plotting the data on these two elements for sherds from the various published studies, alongside the 59 samples from Issa, Pharos and Siculi (Figure 9A), it is possible to both visualise this distinction and use it to shed additional light on the provenance of the three chemical groups detected in the present study. We have to emphasise that plotted specimens were identified as local in cited studies, such as Apulian, Sicilian, and also, local in the north-western Greece and Corinth. For latter and for clarity of the plots we used the term "Greece".

The suspected BSW Italian imports, that form Chemical Group 2, have close $\mathrm{Cr}$ and Ni values to Hellenistic fine ware sherds from Catania, Lentini and Siracuse on Sicily analysed by Barone et al. $(2005,2014)$, as well as several from Canosa and Monte Sannace in Apulia in Italy by Rotunno et al. (1997) and Mangone et al. (2008) (Figure 9A). This pattern is in agreement with hypothesis that these six sherds of Chemical Group 2 from Issa and Pharos are imports and could have come from southern Italy or Sicily. The BSW and GSW sherds that constitute Chemical Group 1 and the RSW sherds of Chemical Group 3 have different values for $\mathrm{Cr}$ and $\mathrm{Ni}$ and plot elsewhere on the graph. They do not appear to be related to the Sicilian or Apulian ceramics, but instead have a composition that can be somewhat comparable to the "Greek" data (Figure 9A). Comparative data on the latter is unfortunately not abundant and, as seen here, are widespread in the $\mathrm{Ni}$ and $\mathrm{Cr}$ plotted graphs. However, those measurements that do exist suggest that Greek fine ware sherds chemically distinct from Sicilian material in terms of the elements $\mathrm{Cr}$ and $\mathrm{Ni}$. On the other hand, some of the Apulian samples have higher values of $\mathrm{Ni}$ and $\mathrm{Cr}$ and some of them are plotted in between the two $\mathrm{Ni}$ vs $\mathrm{Cr}$ groups. These Apulian samples could have been imports from Greece and not local products and it is difficult to clearly distinguish Apulian samples solely based on the values of these two elements. This is also true for analysed Dalmatian samples. High concertation of $\mathrm{Ni}$ and $\mathrm{Cr}$ are indicative of a derivation of these elements from mafic volcanic rocks (Degryse and Breakmans 2014). However, the parts of Greece where samples in question came from is limestone dominated Corfu, Corinth and western Epirus (Jones: 131-121, 169-223 and Whitbread 1996: 263), as are the Dalmatian islands (Figure 1). It is tempting, by plotting only values of $\mathrm{Ni} v \mathrm{Cr}$, to identify all samples with higher values to "Greek" origin, but also it could be misleading if we disregard other provenance criteria, such as prospecting of local raw material. 


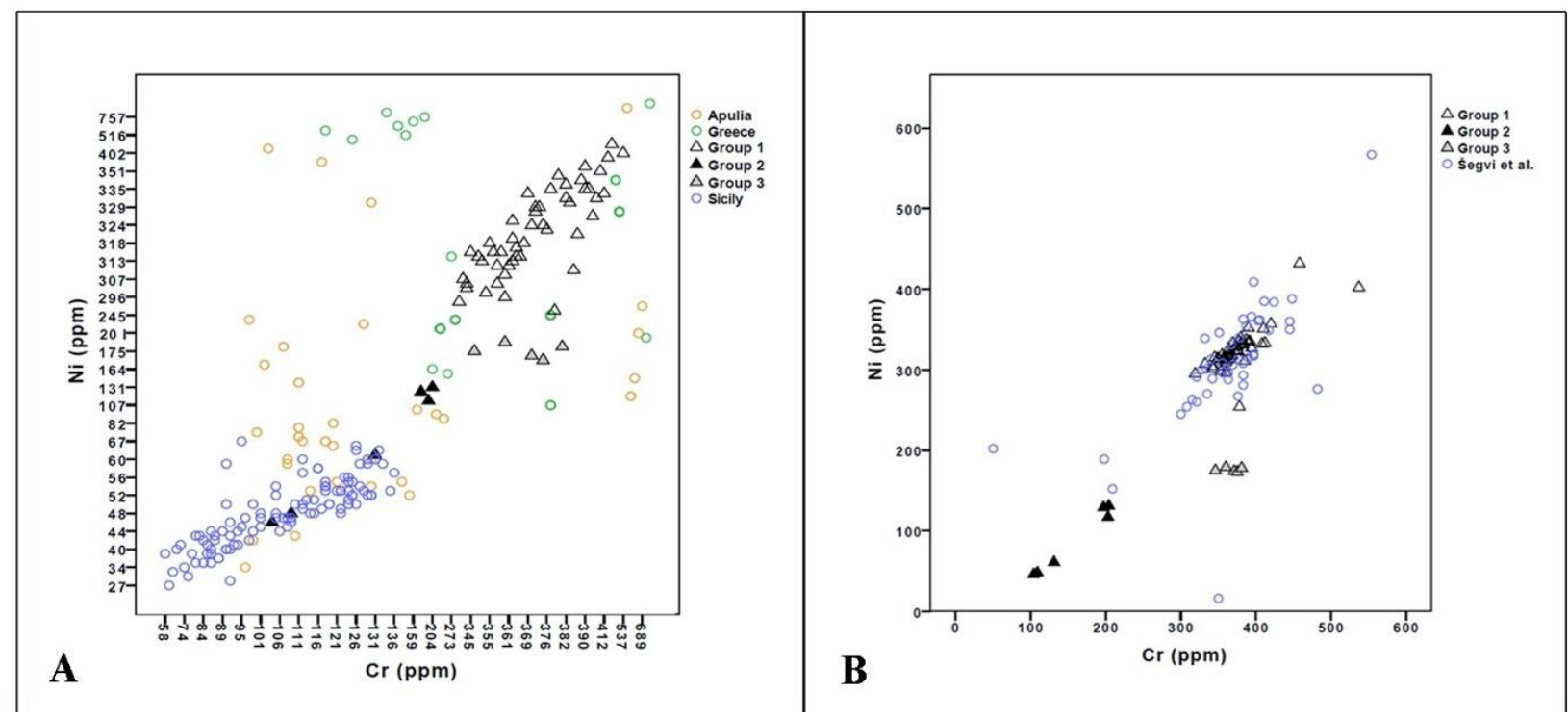

Figure 9. $\mathrm{Cr}$ and Ni comparisons. A. Scatterplot of Ni and $\mathrm{Cr}$ values from published sites in

Sicily, southern Italy and Greece in comparison with chemical group (Figure 4) from

Dalmatia. B. Scatterplot of Ni and Cr values of samples from Dalmatia analysed by Šegvić et al $(2012,2016)$ with chemical groups in Figure 4

There are two other constraints to this approach. First, the available and comparable data are scarce to make full assessments of the $\mathrm{Ni}$ vs $\mathrm{Cr}$ values in different regions, and the alteration of chemical composition due to raw material preparation for ceramic paste that are intrinsically variable (Kilikoglou et al. 1988; Arnold 2000; Buxeda I Garrigós et al. 2003). Braekmans et al. (2011) have demonstrated, on the Hellenistic ware from Turkey, that certain elements, such as $\mathrm{MgO}, \mathrm{K}, \mathrm{Sc}, \mathrm{Ni}, \mathrm{Cr}$ and $\mathrm{TiO} 2$ elevate, while $\mathrm{La}, \mathrm{SiO} 2, \mathrm{~A} 12 \mathrm{O} 3, \mathrm{Na} 2 \mathrm{O} 3$ and $\mathrm{Zr}$ lower due to levigation process of refining raw material and clay paste preparation. The same can be observed by comparing chemical values of the Hellenistic fine tableware and raw material from the islands of Vis and Hvar (Table $1 \mathrm{~A}$ and 2), where elevation of $\mathrm{TiO} 2, \mathrm{MgO}, \mathrm{Na} 2 \mathrm{O}, \mathrm{Cr}$ and $\mathrm{Ni}$ can be noted and decrease of $\mathrm{SiO} 2$ and $\mathrm{Al} 2 \mathrm{O} 3$. Other elements, K, Sc, and $\mathrm{Zr}$ did not show much difference between potsherds and local clays. However, more studies and experiments with raw material and comparison with the paste preparations is needed to make full assessments of chemical alterations in ceramic during production process.

A final set of data that can be used for comparison is that of earlier analyses on Hellenistic fine ware from Issa, Siculi and Cape Ploča by Šegvić et al. (2012, 2016). Many sherds of these analyses closely match the sherds in the present report in terms of the abundance of $\mathrm{Cr}$ and $\mathrm{Ni}$ (Figure 9B). Whilst common data on certified reference materials is not available and discrepancies could therefore exist in terms of the measurement of the two elements. However, the close correspondence seems to indicate that Hellenistic fine ware ceramics of common origins were detected in both studies. The bulk of the fine ware samples analysed by Šegvić et al. $(2012,2016)$ have higher values that match those of Chemical Group 1. As in the present study, these include BSW and GSW sherds from Issa and Siculi, but also GSW from nearby sanctuary at Cape Ploča. Šegvić et al. $(2012,2016)$ interpreted these ceramics as originating from several sources in Dalmatia, including Issa and Siculi, although they did not analyse raw 
materials from these locations. No evidence for pottery production has been uncovered at the harbour site of Siculi and the local production of GSW pottery appears to have been assumed based on its abundance of the samples of similar chemical composition (Šegvić et al. 2012), rather than their similarities with raw materials. Given the extensive trade contacts in the Hellenistic period, movement of vessels from one site to another and possible movement of potters, as well as sharing similar morphological features via cultural transmission, the abundance criteria could not be fully applied without understanding and acknowledging these circumstances. A better explanation of the co-occurrence of typologically and compositionally similar ceramics at the three sites is that they were produced in a single location and distributed for consumption elsewhere.

Taking into account all approaches, typological, compositional and cross-examination with local raw materials, as well with the same types of ware from possible regions of import, local potters in Dalmatia produced fine table ware during the Hellenistic period. The best candidates for the local production are two Greek cities, Issa on the island of Vis and Pharos on the island of Hvar. The best argument for this conclusion is the Chemical Group 1 that consist of sherds from both sites, and they showed closed matching with local Eocene flysch clay. Although, the source of this clay is on the island of Hvar, it is possible that potters, due to lack of available clay on the island of Vis, sailed to the southern part of the neighbouring island of Hvar to collect more suitable clayey raw materials. This argument can be supported with location of Zarače bay on a possible maritime route along the southern parts of the island Hvar and that lead to Issa, on the northern parts of islands of Vis, and also to Pharos, located on the bay on northern part of the island. The mountain range between Zarače bay and Pharos on the island of Hvar made difficult to access this source of raw material by land. It is possible that potters in Pharos also used maritime transport. In this case, to distinguish the production of BSW in the Chemical Group 1 between Pharos and Issa is not possible. They probably produced BSW at the same time, late $4^{\text {th }}$ and $3^{\text {rd }} \mathrm{c}$. BC, and used the same source of raw material based on the microstructure and chemical composition of this group. It also confirmed the hypothesis of local production of fine Hellenistic tableware in central Dalmatia, as the first organized pottery manufacturing in both Dalmatian Greek cities. Regarding the BSW sherds in the same Chemical Group 1 and the fact that this type of ware was not found in Pharos, not at least in large quantities, it is possible to assumed that this type of ware was produce only in Issa and not in Pharos. The historical circumstance may also verify this hypothesis. Namely, after the destruction of Pharos in the II Illyrian war in 219 BC, pottery production ceased and was not continued. Further analysis of sherds from Pharos dated after the late $3^{\text {rd }} \mathrm{c}$. BC may offer clearer picture of pottery production in Pharos in later periods.

The imported pots from southern Italy can be identified in Chemical Group 2, and RSW in the Group 3 is not locally produced, since it does not match with local clays. The origin of production of RSW from Siculi in Resnik cannot be hypothesized, and further analysis of this type of ware is needed.

\section{Conclusions}

The compositional and microstructural analysis of the 60 Hellenistic fine tableware sherds from 3 key sites in Dalmatia, two Greek cities Issa on the island of Vis and Pharos on the island of 
Hvar, and mainland harbour in Siculi in Resnik, presented in this study have confirmed the establishment of pottery manufacturing in Issa and Pharos. Both Dalmatian Greek cities produced BSW at the same time, using the same raw material from Zarače bay, transported via maritime routes to both workshops. After the II Illyrian war and destruction of Pharos in late $3^{\text {rd }}$ c. BC, it seems that production continued in Issa, but not in Pharos, based on the same chemical composition of GSW from Issa with BSW in the Chemical Group 1. Furthermore, the study provides a firm answer, based upon current evidence, were the local variants of southern Italian fine tableware were produced and distributed within Central Dalmatia during the Late Hellenistic period. The geochemical analysis of BSW, GSW and RSW in the present study have shed some much-needed light on this topic. Namely, several BSW sherds that were considered to be south Italian imports, based on their morphological features, have the same chemical composition as the sherds in the Chemical Group 1 and are closely matching with local raw material. This confirmed the importance of compositional analysis of fine Hellenistic tableware in provenance studies as well as the importance of raw material analysis. Slight differences in morphological features of BSW within the same compositional group can imply the developments of this type of ware in cultural context of learning. Local potters were imitating southern Italian imports to developed their own typological characteristics, that sometimes cannot be fully recognised on small sherds, but only on fully preserved vessel. Another aspect of the development within the same workshop, as the Chemical Group 1 has shown, is the production of GSW with the same raw material and the same paste preparation recipe as the BSW, indicating that potters deliberately used different technological process of firing for achieving grey colour of the GSW.

The present study also confirmed trade contacts existed between Dalmatian islands and the settlement in South Italy with analysed sherds of BSW from Issa and Pharos, in Chemical Group 2, that are distinct in their fabrics and chemical composition. The imports in Dalmatia could have also come from different regions, such as norther-western Greece, due to possible close composition of comparable data, but more data are regarded for further examination of this possibility. The current study could not identify the workshop in Siculi in Resnik, and regarding its nature as a harbour on the mainland and on the trade routes, it received products from Issa and Pharos, and maybe further afar with distinct RSW sherds, that don't belong to either local Dalmatian production nor to southern Italian imports.

It therefore appears that, taking advantage of extensive Hellenistic trade networks, fine table ware were produced in Central Dalmatia by emerging local centres. These may have been transported and consumed by Iron Age communities on the Adriatic coast via the harbour site of Siculi in Resnik.

\section{ACKNOWLEDGEMENTS}

The authors of the paper would like to thank Dr Branko Kirigin, Dr Sara Popović, Andrea Devlahović and Aldo Čavić from the City Museum in Stari Grad on Hvar, Boris Čargo from the Archaeological Museum in Spit and Ivanka Kamenjarin from the Municipality Museum Kaštela for kindly providing the material for analysis. Dr Tvrtko Korbar from Croatian Geological Survey for his assistance in understanding the local geology of island of Hvar and Vis. Also, to Croatian Geological Survey for providing us with necessary geological maps. 
Many thanks to Prof Emer Marino Maggetti for his guidance and advices during the moment of doubts when dealing with such complex material, and Dr Ildiko Katona Serneels for microphotographs and assistance with the optical microscopy from the Department of Geosciences University of Fribourg. We would also like to thank Jelena Jovanović, Tonći Sesar and Damir Kliškić from the Archaeological Museum Split for providing photos and permit for publication oinochoe vessels in Figure 2.

The research that have led to these results has received funding from the European Commission FP7 2007-2013 under the grant agreement $n^{\circ} 291823$ Marie Curie FP7-PEOPLE-2011COFUND- NEWFELPRO, as part of the project Connecting Adriatic with Mediterranean: Tracing Ancient Ceramic Workshop and Networks in the last centuries BC (CAMTAWN) under the grant agreement 70 . 
Table 1A. Details of analysed Late Hellenistic Fine sherds excavated from suspected pottery kilns at the settlements of Issa (VIS) and Pharos (SGP), and from the harbour site of Siculi in Resnik (RES), including their composition as measured by WD-XRF

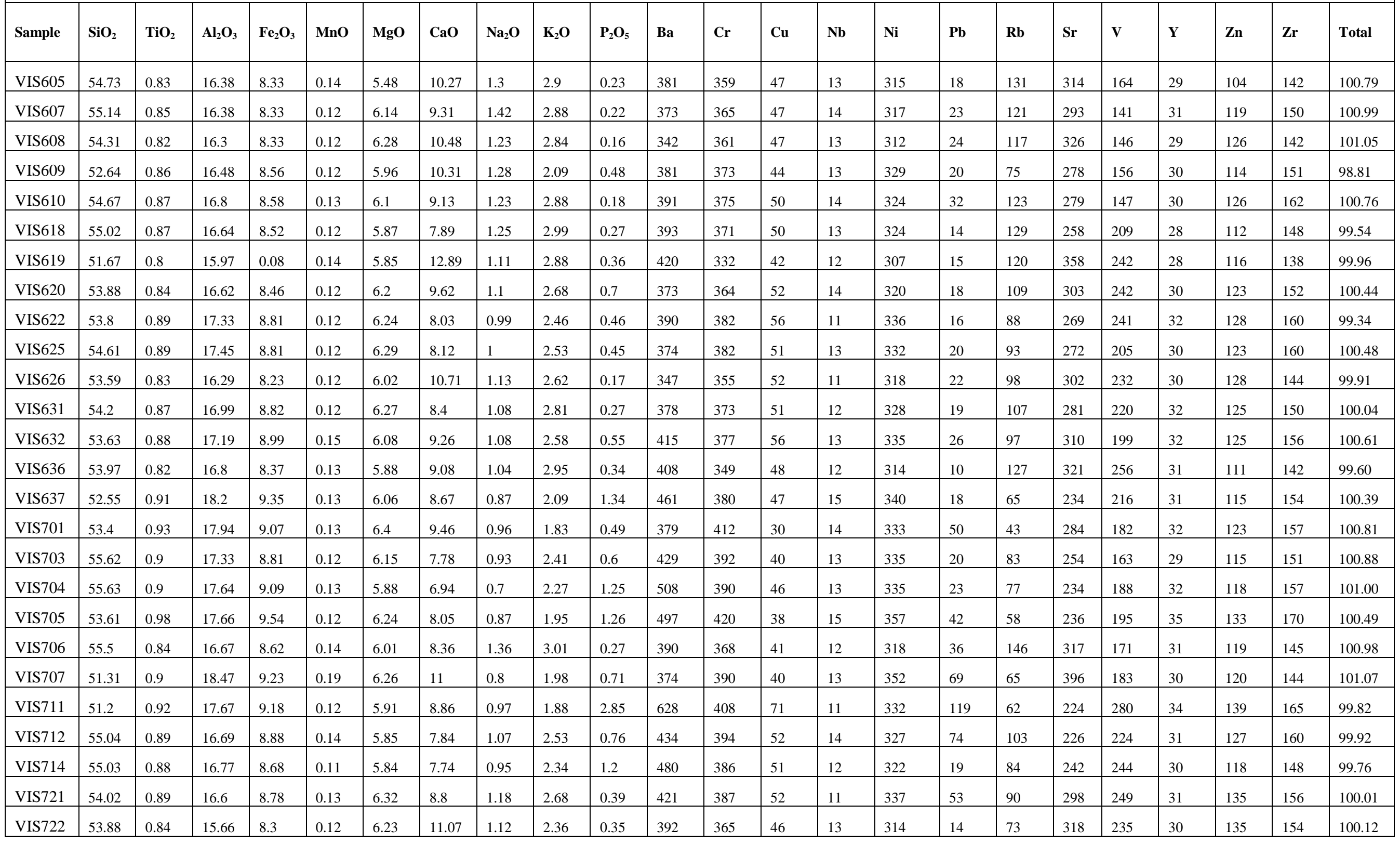




\begin{tabular}{|c|c|c|c|c|c|c|c|c|c|c|c|c|c|c|c|c|c|c|c|c|c|c|c|}
\hline SGP601 & 52.64 & 0.76 & 15.09 & 8.46 & 0.12 & 6.45 & 12.45 & 1.11 & 2.58 & 0.35 & 418 & 458 & 42 & 12 & 432 & 19 & 109 & 318 & 205 & 31 & 104 & 140 & 99.86 \\
\hline SGP611 & 54.54 & 0.86 & 16.99 & 8.59 & 0.13 & 5.96 & 8.53 & 1.19 & 3.11 & 0.31 & 406 & 364 & 48 & 14 & 326 & 0 & 137 & 299 & 171 & 31 & 124 & 151 & 100.42 \\
\hline SGP614 & 54.5 & 0.81 & 15.95 & 8.05 & 0.12 & 5.9 & 8.61 & 1.29 & 3.18 & 0.31 & 376 & 343 & 48 & 14 & 304 & 7 & 140 & 299 & 257 & 30 & 123 & 144 & 98.92 \\
\hline SGP616 & 54.74 & 0.82 & 16.45 & 8.15 & 0.12 & 5.8 & 8.44 & 1.68 & 3.18 & 0.32 & 378 & 350 & 51 & 13 & 313 & 14 & 143 & 299 & 368 & 31 & 119 & 145 & 99.90 \\
\hline SGP619 & 55.39 & 0.83 & 16.36 & 8.24 & 0.12 & 5.9 & 8.69 & 1.18 & 3.15 & 0.25 & 406 & 357 & 51 & 14 & 315 & 17 & 143 & 304 & 273 & 33 & 118 & 149 & 100.31 \\
\hline SGP622 & 52.19 & 0.82 & 16.13 & 8.38 & 0.16 & 4.81 & 12.03 & 0.89 & 2.53 & 1.56 & 518 & 343 & 52 & 12 & 301 & 11 & 100 & 343 & 268 & 31 & 108 & 153 & 99.74 \\
\hline SGP626 & 56.31 & 0.83 & 15.79 & 8.09 & 0.12 & 5.28 & 9.02 & 1.19 & 2.92 & 0.58 & 397 & 360 & 43 & 14 & 296 & 20 & 132 & 285 & 238 & 31 & 109 & 171 & 100.34 \\
\hline SGP634 & 51.38 & 0.78 & 15.75 & 7.99 & 0.14 & 4.91 & 15.33 & 1.31 & 1.5 & 0.83 & 420 & 319 & 38 & 13 & 295 & 14 & 97 & 375 & 237 & 28 & 89 & 132 & 100.12 \\
\hline SGP635 & 54.83 & 0.86 & 16.53 & 8.51 & 0.13 & 5.74 & 8.45 & 1.07 & 2.99 & 0.74 & 401 & 364 & 39 & 14 & 313 & 18 & 130 & 286 & 271 & 30 & 122 & 149 & 100.07 \\
\hline SGP636 & 53.81 & 0.84 & 16.53 & 8.42 & 0.14 & 5.96 & 10.01 & 1.03 & 3.13 & 0.29 & 396 & 345 & 51 & 12 & 315 & 15 & 135 & 339 & 282 & 29 & 121 & 140 & 100.37 \\
\hline SGP637 & 56.02 & 0.84 & 16.17 & 8.09 & 0.12 & 5.29 & 8.09 & 1.32 & 3.1 & 0.57 & 397 & 360 & 43 & 13 & 309 & 15 & 139 & 260 & 277 & 32 & 114 & 159 & 99.81 \\
\hline SGP638 & 52.72 & 0.87 & 17.62 & 9.08 & 0.14 & 5.2 & 8.95 & 0.76 & 3.53 & 0.73 & 576 & 537 & 59 & 14 & 402 & 21 & 157 & 250 & 242 & 32 & 133 & 153 & 99.86 \\
\hline SGP639 & 54.26 & 0.8 & 16.04 & 8.04 & 0.13 & 4.9 & 11.96 & 1.26 & 2.97 & 0.27 & 392 & 353 & 55 & 12 & 298 & 21 & 132 & 292 & 142 & 28 & 107 & 134 & 100.84 \\
\hline RES603 & 53.23 & 0.82 & 16.06 & 8.29 & 0.12 & 6.07 & 11.14 & 1.22 & 2.4 & 0.39 & 409 & 358 & 46 & 12 & 312 & 7 & 80 & 323 & 185 & 30 & 125 & 148 & 99.95 \\
\hline RES610 & 52.58 & 0.86 & 17.24 & 8.54 & 0.12 & 6.08 & 10.1 & 0.95 & 2.19 & 0.95 & 516 & 369 & 44 & 14 & 333 & 9 & 70 & 346 & 217 & 31 & 127 & 145 & 99.83 \\
\hline RES611 & 55.77 & 0.89 & 16.62 & 8.32 & 0.12 & 5.58 & 6.84 & 1.44 & 2.94 & 0.29 & 435 & 374 & 41 & 14 & 329 & 20 & 130 & 251 & 256 & 29 & 107 & 158 & 99.03 \\
\hline RES612 & 52.48 & 0.84 & 16.78 & 8.21 & 0.14 & 5.69 & 10.79 & 1.23 & 2.61 & 1.04 & 611 & 366 & 40 & 12 & 314 & 16 & 97 & 358 & 256 & 32 & 103 & 145 & 100.05 \\
\hline RES701 & 53.31 & 0.97 & 18.48 & 9.35 & 0.15 & 5.8 & 7.1 & 0.92 & 2.02 & 2.28 & 812 & 410 & 44 & 14 & 351 & 13 & 55 & 279 & 288 & 33 & 121 & 163 & 100.64 \\
\hline RES702 & 54.78 & 0.88 & 17.12 & 8.31 & 0.13 & 5.29 & 8.52 & 1.05 & 2.41 & 1.08 & 675 & 385 & 45 & 13 & 311 & 16 & 101 & 281 & 246 & 32 & 128 & 157 & 99.81 \\
\hline $\begin{array}{l}\text { RES703 } \\
\text { A }\end{array}$ & 56.96 & 0.88 & 17.55 & 8.03 & 0.1 & 5.57 & 5.98 & 1.12 & 2.78 & 0.66 & 595 & 383 & 36 & 14 & 331 & 6 & 123 & 240 & 245 & 31 & 128 & 154 & 99.86 \\
\hline $\begin{array}{l}\text { RES703 } \\
\text { B }\end{array}$ & 51.19 & 0.75 & 14.79 & 7.15 & 0.12 & 3.86 & 17.72 & 1.01 & 1.87 & 1.76 & 841 & 378 & 50 & 9 & 254 & 1 & 80 & 438 & 211 & 31 & 131 & 144 & 100.48 \\
\hline RES705 & 53.88 & 0.87 & 17.02 & 8.29 & 0.12 & 5.77 & 9.16 & 0.97 & 2.32 & 1.01 & 549 & 376 & 42 & 12 & 323 & 77 & 83 & 287 & 252 & 32 & 138 & 153 & 99.65 \\
\hline VIS601 & 54.32 & 0.74 & 15.64 & 6.28 & 0.08 & 2.66 & 11.25 & 1.18 & 2.35 & 4.83 & 441 & 203 & 19 & 15 & 117 & 21 & 101 & 574 & 103 & 31 & 115 & 166 & 99.52 \\
\hline SGP602 & 58.47 & 0.69 & 15.47 & 5.77 & 0.09 & 2.42 & 13.4 & 1.14 & 2.64 & 0.52 & 340 & 104 & 26 & 16 & 46 & 20 & 107 & 285 & 96 & 29 & 95 & 171 & 100.76 \\
\hline SGP603 & 56.74 & 0.72 & 15.57 & 5.86 & 0.11 & 2.37 & 14.88 & 1.07 & 2.68 & 0.59 & 349 & 109 & 29 & 15 & 48 & 22 & 115 & 341 & 105 & 29 & 100 & 165 & 100.74 \\
\hline
\end{tabular}




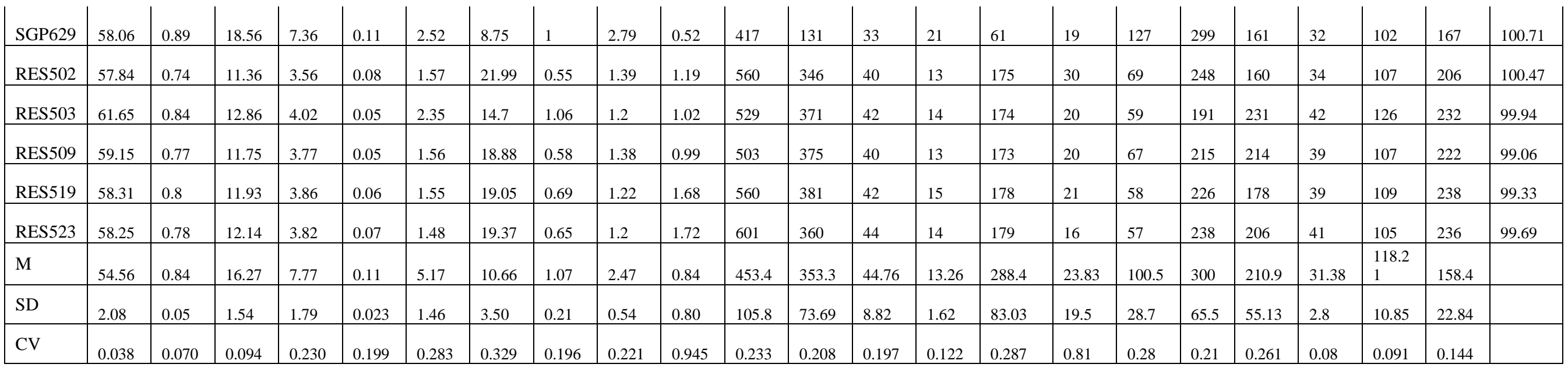

\begin{tabular}{|l|l|l|l|l|l|}
\hline \multicolumn{2}{|c|}{ Table 1A. Geochemical groups determined by PCA (Figure 5A) and their Mean, Standard } \\
Deviation and Coefficient of Variance, with Petrographic grouping
\end{tabular}




\begin{tabular}{|c|c|c|c|c|c|}
\hline VIS625 & Issa & $\begin{array}{ll}\text { Black } & \text { Slip } \\
\text { Ware } & \end{array}$ & Local imitation & & 1 \\
\hline VIS626 & Issa & $\begin{array}{l}\text { Black Slip } \\
\text { Ware }\end{array}$ & Local imitation & & 1 \\
\hline VIS631 & Issa & $\begin{array}{ll}\text { Black } & \text { Slip } \\
\text { Ware } & \end{array}$ & Local imitation & & 1 \\
\hline VIS632 & Issa & $\begin{array}{l}\text { Black Slip } \\
\text { Ware }\end{array}$ & Local imitation & & 1 \\
\hline VIS636 & Issa & $\begin{array}{ll}\text { Black } & \text { Slip } \\
\text { Ware } & \\
\end{array}$ & Local imitation & & 1 \\
\hline VIS637 & Issa & $\begin{array}{l}\text { Black } \\
\text { Ware }\end{array}$ & Local imitation & & 1 \\
\hline VIS701 & Issa & Grey Slip Ware & Local & 2 & 1 \\
\hline VIS703 & Issa & Grey Slip Ware & Local & 2 & 1 \\
\hline VIS704 & Issa & Grey Slip Ware & Local & 2 & 1 \\
\hline VIS705 & Issa & Grey Slip Ware & Local & 2 & 1 \\
\hline VIS706 & Issa & Grey Slip Ware & Local & 2 & 1 \\
\hline VIS707 & Issa & Grey Slip Ware & Local & & 1 \\
\hline VIS711 & Issa & Grey Slip Ware & Local & & 1 \\
\hline VIS712 & Issa & Grey Slip Ware & Local & & 1 \\
\hline VIS714 & Issa & Grey Slip Ware & Local & & 1 \\
\hline VIS721 & Issa & Grey Slip Ware & Local & & 1 \\
\hline VIS722 & Issa & Grey Slip Ware & Local & & 1 \\
\hline SGP601 & Pharos & $\begin{array}{l}\text { Black } \quad \text { Slip } \\
\text { Ware }\end{array}$ & Local imitation & & 1 \\
\hline SGP611 & Pharos & $\begin{array}{ll}\text { Black } & \text { Slip } \\
\text { Ware } & \end{array}$ & Local imitation & 1 & 1 \\
\hline SGP614 & Pharos & $\begin{array}{ll}\text { Black } & \text { Slip } \\
\text { Ware } & \\
\end{array}$ & Local imitation & 1 & 1 \\
\hline SGP616 & Pharos & $\begin{array}{ll}\text { Black } & \text { Slip } \\
\text { Ware } & \end{array}$ & Local imitation & 1 & 1 \\
\hline SGP619 & Pharos & $\begin{array}{l}\text { Black } \\
\text { Ware }\end{array}$ & Local imitation & 1 & 1 \\
\hline SGP622 & Pharos & $\begin{array}{ll}\text { Black } & \text { Slip } \\
\text { Ware } & \\
\end{array}$ & Local imitation & 1 & 1 \\
\hline SGP626 & Pharos & $\begin{array}{l}\text { Black Slip } \\
\text { Ware }\end{array}$ & Local imitation & 1 & 1 \\
\hline
\end{tabular}




\begin{tabular}{|c|c|c|c|c|c|}
\hline SGP634 & Pharos & $\begin{array}{ll}\text { Black } & \text { Slip } \\
\text { Ware } & \end{array}$ & Local imitation & & 1 \\
\hline SGP635 & Pharos & $\begin{array}{l}\text { Black Slip } \\
\text { Ware }\end{array}$ & Apulian import & & 1 \\
\hline SGP636 & Pharos & $\begin{array}{ll}\text { Black } & \text { Slip } \\
\text { Ware } & \end{array}$ & Apulian import & & 1 \\
\hline SGP637 & Pharos & $\begin{array}{l}\text { Black Slip } \\
\text { Ware }\end{array}$ & Local imitation & & 1 \\
\hline SGP638 & Pharos & $\begin{array}{ll}\text { Black } & \text { Slip } \\
\text { Ware } & \\
\end{array}$ & Local imitation & 1 & 1 \\
\hline SGP639 & Pharos & $\begin{array}{l}\text { Black } \\
\text { Ware }\end{array}$ & Local imitation & 1 & 1 \\
\hline RES602 & Resnik & $\begin{array}{l}\text { Black Slip } \\
\text { Ware }\end{array}$ & Local imitation & & 1 \\
\hline RES603 & Resnik & $\begin{array}{ll}\text { Black } & \text { Slip } \\
\text { Ware } & \\
\end{array}$ & Local imitation & & 1 \\
\hline RES610 & Resnik & $\begin{array}{ll}\text { Black } & \text { Slip } \\
\text { Ware } & \\
\end{array}$ & Local imitation & & 1 \\
\hline RES611 & Resnik & $\begin{array}{ll}\text { Black } & \text { Slip } \\
\text { Ware } & \end{array}$ & Local imitation & & 1 \\
\hline RES612 & Resnik & $\begin{array}{ll}\text { Black } & \text { Slip } \\
\text { Ware } & \end{array}$ & Local imitation & & 1 \\
\hline RES701 & Resnik & Grey Slip Ware & Local & & 1 \\
\hline RES702 & Resnik & Grey Slip Ware & Local & & 1 \\
\hline RES703A & Resnik & Grey Slip Ware & Local & & 1 \\
\hline RES703B & Resnik & Grey Slip Ware & Local & & 1 \\
\hline RES705 & Resnik & Grey Slip Ware & Local & & 1 \\
\hline VIS601 & Issa & $\begin{array}{ll}\text { Black } & \text { Slip } \\
\text { Ware } & \end{array}$ & Apulian import & 3 & 2 \\
\hline VIS603 & Issa & $\begin{array}{l}\text { Black Slip } \\
\text { Ware }\end{array}$ & Apulian import & 3 & 2 \\
\hline VIS604 & Issa & $\begin{array}{ll}\text { Black } & \text { Slip } \\
\text { Ware } & \end{array}$ & Apulian import & & 2 \\
\hline SGP602 & Pharos & $\begin{array}{ll}\text { Black } & \text { Slip } \\
\text { Ware } & \end{array}$ & Apulian import & 3 & 2 \\
\hline SGP603 & Pharos & $\begin{array}{l}\text { Black } \\
\text { Ware }\end{array}$ & Apulian import & 3 & 2 \\
\hline SGP629 & Pharos & $\begin{array}{ll}\text { Black } & \text { Slip } \\
\text { Ware } & \\
\end{array}$ & Apulian import & & 2 \\
\hline
\end{tabular}




\begin{tabular}{|c|c|c|c|c|c|c|c|c|c|c|c|c|c|c|c|c|c|c|c|c|c|c|}
\hline \multirow{2}{*}{\multicolumn{2}{|c|}{$\begin{array}{l}\text { RES502 } \\
\text { RES503 }\end{array}$}} & \multicolumn{3}{|c|}{ Resnik } & \multicolumn{2}{|c|}{ Red Slip Ware } & \multicolumn{3}{|c|}{$\begin{array}{l}\text { Import from Greek } \\
\text { unknown workshop }\end{array}$} & & & \multicolumn{3}{|l|}{3} & & & & & & & & \\
\hline & & \multicolumn{3}{|c|}{ Resnik } & \multicolumn{2}{|c|}{ Red Slip Ware } & \multicolumn{3}{|c|}{$\begin{array}{l}\text { Import from Greek } \\
\text { unknown workshop }\end{array}$} & & & \multicolumn{3}{|l|}{3} & & & & & & & & \\
\hline \multicolumn{2}{|c|}{ RES509 } & \multicolumn{3}{|c|}{ Resnik } & \multicolumn{2}{|c|}{ Red Slip Ware } & \multicolumn{3}{|c|}{$\begin{array}{l}\text { Import from Greek } \\
\text { unknown workshop }\end{array}$} & & & \multicolumn{3}{|l|}{3} & & & & & & & & \\
\hline \multicolumn{2}{|c|}{ RES519 } & \multicolumn{3}{|c|}{ Resnik } & \multicolumn{2}{|c|}{ Red Slip Ware } & \multicolumn{3}{|c|}{$\begin{array}{l}\text { Import from Greek } \\
\text { unknown workshop }\end{array}$} & & & \multicolumn{3}{|l|}{3} & & & & & & & & \\
\hline \multicolumn{2}{|c|}{ RES523 } & \multicolumn{3}{|c|}{ Resnik } & \multicolumn{2}{|c|}{ Red Slip Ware } & \multicolumn{3}{|c|}{$\begin{array}{l}\text { Import from Greek } \\
\text { unknown workshop }\end{array}$} & & & \multicolumn{3}{|l|}{3} & & & & & & & & \\
\hline & $\mathrm{SiO}_{2}$ & $\mathrm{TiO}_{2}$ & $\mathrm{Al}_{2} \mathrm{O}_{3}$ & $\mathrm{Fe}_{2} \mathrm{O}_{3}$ & $\begin{array}{c}\text { Mn } \\
\mathbf{O}\end{array}$ & MgO & $\mathrm{CaO}$ & $\mathrm{Na}_{2} \mathrm{O}$ & $\mathrm{K}_{2} \mathrm{O}$ & $\mathbf{P}_{2} \mathrm{O}_{5}$ & $\mathbf{B a}$ & $\mathrm{Cr}$ & $\mathrm{Cu}$ & $\mathrm{Nb}$ & $\mathbf{N i}$ & $\mathbf{P b}$ & $\mathbf{R b}$ & Sr & $\mathbf{V}$ & $\mathbf{Y}$ & Zn & $\mathbf{Z r}$ \\
\hline \multicolumn{23}{|c|}{ Group 1} \\
\hline $\mathrm{M}$ & 53.97 & 0.86 & 16.75 & 8.36 & 0.13 & 5.82 & 9.50 & 1.11 & 2.61 & 0.68 & 451.37 & 375.92 & 47.18 & 12.88 & 324.37 & 24.37 & 104.35 & 295.33 & 224.39 & 30.73 & 120.22 & 150.80 \\
\hline $\mathrm{CV}$ & 0.03 & 0.05 & 0.05 & 0.15 & 0.11 & 0.08 & 0.22 & 0.17 & 0.17 & 0.81 & 0.24 & 0.09 & 0.15 & 0.09 & 0.08 & 0.89 & 0.27 & 0.15 & 0.21 & 0.05 & 0.08 & 0.06 \\
\hline \multicolumn{23}{|c|}{ Group 2} \\
\hline M & 55.63 & 0.75 & 16.00 & 6.29 & 0.10 & 2.82 & 13.43 & 1.07 & 2.43 & 1.83 & 389.00 & 158.00 & 27.67 & 16.00 & 88.67 & 21.50 & 101.33 & 401.83 & 111.83 & 30.33 & 108.00 & 164.33 \\
\hline $\mathrm{SD}$ & 2.51 & 0.07 & 1.26 & 0.57 & 0.01 & 0.52 & 3.04 & 0.07 & 0.32 & 1.71 & 40.72 & 48.39 & 6.31 & 2.53 & 41.14 & 1.87 & 19.38 & 113.92 & 24.32 & 1.21 & 11.98 & 5.43 \\
\hline $\mathrm{CV}$ & 0.05 & 0.09 & 0.08 & 0.09 & 0.13 & 0.18 & 0.23 & 0.07 & 0.13 & 0.93 & 0.10 & 0.31 & 0.23 & 0.16 & 0.46 & 0.09 & 0.19 & 0.28 & 0.22 & 0.04 & 0.11 & 0.03 \\
\hline \multicolumn{23}{|c|}{ Group 3} \\
\hline M & 59.04 & 0.79 & 12.01 & 3.81 & 0.06 & 1.70 & 18.80 & 0.71 & 1.28 & 1.32 & 550.60 & 366.60 & 41.60 & 13.80 & 175.80 & 21.40 & 62.00 & 223.60 & 197.80 & 39.00 & 110.80 & 226.80 \\
\hline $\mathrm{CV}$ & 0.03 & 0.05 & 0.05 & 0.04 & 0.21 & 0.21 & 0.14 & 0.29 & 0.08 & 0.27 & 0.07 & 0.04 & 0.04 & 0.06 & 0.01 & 0.24 & 0.09 & 0.10 & 0.14 & 0.08 & 0.08 & 0.06 \\
\hline
\end{tabular}


Table 2. Details of raw material field samples collected from the islands of Hvar and Vis and their composition as measured by WD-XRF

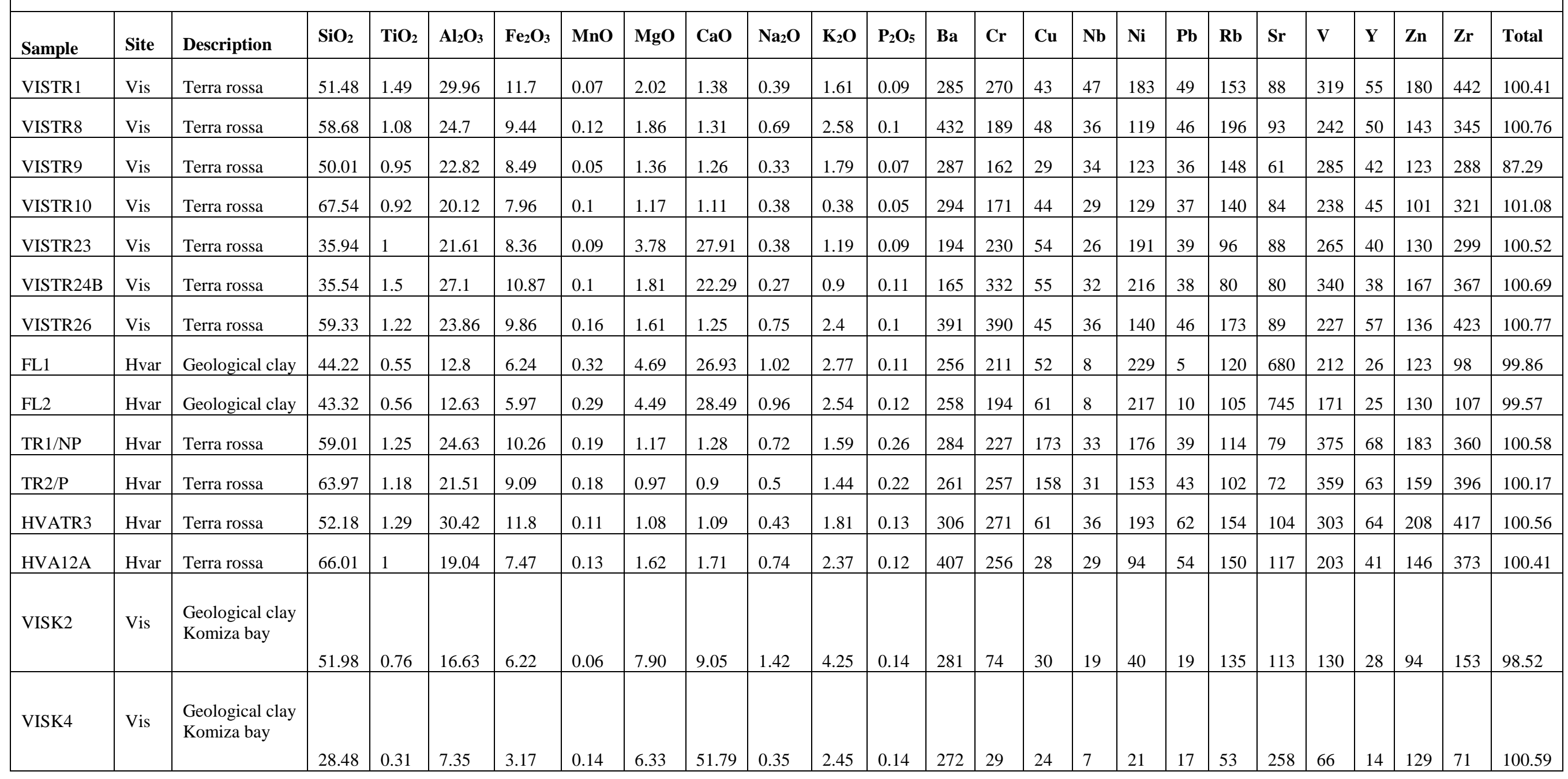




\section{REFERENCES}

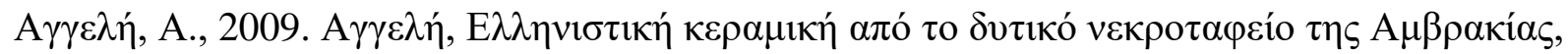

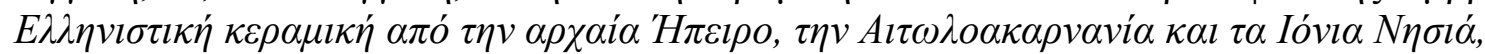
Athens, pp. 163-178.

Aitchison, J., 1986. The Statistical Analysis of Compositional Data. London: Chapman and Hall.

Arnold, D. E., 1985. Ceramic Theory and Cultural Process. Cambridge: Cambridge University Press.

Arnold, D. E., 2000. Does the Standardization of Ceramic Pastes Really Mean Specialization? Journal of Archaeological Method and Theory 7 (4), pp. 333-375.

Barone, G., Lo Giudice, A., Mazzoleni, P. and Pezzino, A., 2005. Chemical characterisation and statistical multivariable analysis of ancient pottery from Messina, Catania, Lentini and Siracusa (Sicily), Archaeometry 47 (4), pp. 745-762.

Barone, G., Crupi, V., Longo, F., Majolino, D., Mazzoleni, P., Spagnolo, G., Venuti, V. and Aquilia, E., 2011. Potentiality of non-destrutive XRF analysis for determination of Corinthian B amphorae provenance, $X$-ray Spectrometry 40, pp. 333-337.

Barone, G., Mazzoleni P., Aquilia, A. and Barbera, G., 2014. The Hellenistic and Roman Syracuse (Sicily) fine pottery production explored by chemical and petrographic analysis, Archaeometry 56 (1), pp. 70-87.

Braekmans, D., Degryse, P., Poblome, J., Neyt, B., Vyncke, K. and Waelkens, M., 2011. Understanding ceramic variability: an archaeometrical interpretations of the Classical and Hellensitic ceramics at Düzen Tepe and Sagalassos (Southwest Turkey), Journal of Archaeological Science 38, pp. 2011-2115.

Buxeda I Garrigós, J., Cau Ontiveros, M. A. and Kilikoglou, V., 2003. Chemical variability in clays and potter from a traditional cooking pot production village: testing assumptions in Pereruela, Archaeometry 45 (1), pp. 1-17.

Carre, M.-B. and Pesavento Mattioli, S., 2003. Anfore e commerci nell'Adriatico". In: L'arcgaeologia dell'Adriatico dalla Preistoria al Medievo. Convegno Rimini 2001, Firenze, pp. 268-285.

Carre, M.-B., Monsieur, P. and Pesavento Mattiolli, S., 2014. Transport amphorae Lamboglia 2 and Dressel 6A: Italy and/or Dalmatia? Some clarifications, Journal of Roman Archaeology 27, pp. 417-428.

Costin, C. L. (1991). Craft specialization: Issues in defining, documenting, and explaining the organization of production. In: Schiffer, M. B. (Ed.), Archaeological Method and Theory, Vol. 3, University of Arizona Press, Tucson, pp. 1-56.

Costin, C. 1., 2000. The Use of Ethnoarchaeology for the Archaeological Study of Ceramic Production, Journal of Archaeological Method and Theory, Vol. 7, No. 4, pp. 377-403. 
Cuomo di Caprio. N., 2007. Ceramica in archeologia 2, Antiche tecniche di lavorazione e moderni metodi di indagine, Rome: L'Erma di Bretschneider,

Čargo, B. and Miše, M., 2010. Potter production in Issa, Vjesnik za arheologiju i povijest dalmatinsku 103, pp. 7-40.

Degryse, P. and Braekmans, D., 2014. Elemental and Isotopic Analysis of Ancient Ceramics and Glass. In: Turekian, K. and Holland, H. (Eds.), Treatise on Geochemistry 14. 14, $2^{\text {nd }}$ edition, pp. 191-207. http://dx.doi.org/10.1016/B978-0-08-095975-7.01215-8

Farnsworth, M., Perlman, I. and. Asaro, F., 1977, A Neutron Activation Study of Their Pottery, American Journal of Archaeology 81 (4), p. 455-468.

Freestone, I. C., 2001. Post-depositional changes in archaeological ceramics and glasses. In: Brothwell, D. R. and Pollard, A., M. (Eds), Handbook of Archaeological Science, John Wiley, New York, pp. 615-625.

Gamberini, A., 2014. Anfore. In: Mazzeo Saracino, L. (Ed.), Scavi di Suasa I. I reperti ceramici e vitrei dalla Domus dei Coiedii, Bologna, pp. 533-717.

Gandon, E., Roux, V. and Coyle, T., 2014 (a), Copying error: Predictable directions for a socalled random phenomenon, Journal of Anthropological Archaeology 33, pp. 99-107. http://dx.doi.org/10.1016/j.jaa.2013.12.003

Gandon, E., Coyle, T. and Bootsma, R. J., 2014 (b), When handicraft experts face novelty: Effects of shape and wheel familiarity on individual and community standardization of ceramic vessels, Journal of Anthropological Archaeology 35, pp. 289-296. http://dx.doi.org/10.1016/j.jaa.2014.06.008

Green, J. R., 2001. Gnathia and Other Overpainted Wares of Italy and Sicily: a Survey. In: Lévêque, P. and Morel, J. P., (Eds.), Céramiques hellénistiques et romaines, III, Paris, pp. 57103.

Gosselain, O. P., 2000. Materializing identities: An African perspective, Journal of Archaeological Method and Theory 7, pp. 187-217.

Horden, P. and Purcell, N., 2000. The Corrupting Sea. A Study of Mediterranean History, Oxford.

Hudson, N., Gentelli, L. and Trampier, J., 2018. Importing Clay for Local Pottery Production in the 4th Century B.C. at Tell el-Timai, Egypt, Journal of Field Archaeology, Vol. 43, No. 1, pp. 1-16.

Jones, R. E., 1986. Greek and Cypriot Pottery. A review of scientific studies, Fitch Laboratory Occasional Paper 1, British School at Athens.

Kilikoglou, V., Maniatis, Y. and Grimanis, A. P., 1988. The effect of purification and firing of clays on trace element provenance studies, Archaeometry 30 (1), pp. 37-46.

Kirigin, B., 1985. Zapažanja o helenističkoj nekropoli Isse (Observations on the Hellenistic necropolis at Issa), Materijali XX, pp. 91-110. 


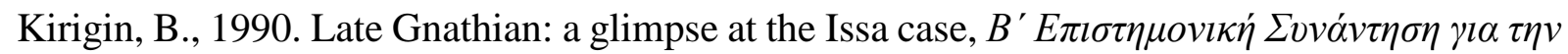

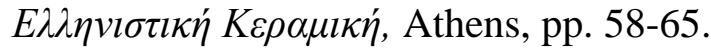

Kirigin, B., 1994. Grčko -italske amfore na Jadranu, Arheološki Vesnik 45, pp. 15-24.

Kirigin, B., 1999. The Greeks in Central Dalmatia. In: Braccesi, L. and Graciotti, S., (Eds.), La Dalmatia e l'altra sponda. Problemi di archaeologhia adriatica, Firenze, pp. 147-164.

Kirigin, B., 2018. Pharos, Greek amphorae and wine production. In: Katsonopoulou, D. (Ed.), Proceedings of the fourth international conference on the archaeology of Paros and the Cyclades Paroikia, Paros, 11-14 June 2015, Paros IV. Paros and its colonies, pp. 397-420.

Kirigin, B., Hayes, J., and Leach, P., 2002. Local pottery production at Pharos. In: Cambi, N., Čače, S. and Kirigin, B., (Eds.), Grčki utjecaj na istočnoj obali Jadrana/Greek influence along the east Adriatic coast, Split, Književni krug, pp. 241-260.

Kirigin, B., Katunarić, T. and Šešelj, L., 2006. Preliminary notes on some economic and social aspects of amphorae and fine ware pottery from Central Dalmatia, 4th-1st BC. In: Lenzi, F. (Ed.), Rimini e l'Adritico nell'eta delle guerre puniche. Atti del Convegno Internazionale di Studi Rimini, 2004, Bologna, pp. 191-226.

Korbar, T., Belak, M., Fuček, L., Husinec, A., Oštrić, N., Palenik, D. and Vlahović, I., 2012. Osnovna geološka karta Republike Hrvatske mjerila 1:50 000 - list Vis 3 i Biševo 1 (Basic Geological Map of the Republic of Croatia scale 1:50.000 - sheet Vis 3 and Biševo 1). Hrvatski geološki institut (Croatian Geological Survey), Zavod za geologiju (Department of Geology), Zagreb.

Lahi, B., 2009. Amfora transporti te shekujve 3-1 pr. Kr. Ne Shqiperi, Lezhe.

Lemonnier, P., 1986. The Study of Material Culture Today: Toward an Anthropology of Technical Systems, Journal of Anthropological Archaeology 5, pp. 147 - 186.

Mangone, A., Giannossa, L., C., Ciancio, A., Laviano, R., Traini, A., 2008. Technological features of Apulian Red figured pottery, Journal of Archaeological Science 35, pp. 1533-1541.

Mirti, P. and Davit, P., 2001. Technological characterisation of Campanian pottery of Type A, $\mathrm{B}$ and $\mathrm{C}$ and of regional products from ancient Calabria (Southern Italy), Archaeometry 43 (1), pp. 19-33.

Miše, M., 2010. Preliminarne analize keramike pronađene unutar bedema antičke Ise (Preliminary analysis of pottery found intra muros of Issa, Izdanja Hrvatskog Arheološkog Društva 26, Zagreb, pp. 69-81.

Miše, M., 2013. A contribution to the study of Gnathia ware from Issa, Vjesnik za arheologiju i povijest dalmatinsku 106, pp. 99-129.

Miše, M., 2015. Gnathia and Related Hellenistic ware on the Eastern Adriatic, Oxford: Archaeopress.

Miše, M., 2017. The Hellenistic ware from the indigenous necropolis at Gradina in Dragišić near Šibenik, Croatia. In: Demicheli, D. (Ed.), Illyrica Antiqua. Proceedings of the International Conference in Šbenik 12th -15th September 2013, Zagreb, pp. 83-104. 
Miše, M., 2019. Drinking wine in Liburnia: Hellenistic ware in the indigenous necropolis Dragišić in Dalmatia, Croatia. In: A. Peignard-Giros (Ed.), Daily Life In A Cosmopolitan World, IARPotHP 2, Vienna, pp. 175-186.

Miše, M., Serneels, V., Matana, A., Montanari, A., and Kirigin, B., 2019, Provenance studies of amphorae from the Greek colony Pharos on the island of Hvar, Croatia. In: Koeberl, C., and Bice, D.M., (Eds.), 250 Million Years of Earth History in Central Italy: Celebrating 25 Years of the Geological Observatory of Coldigioco: Geological Society of America Special Paper 542, p. 471-499, https://doi.org/10.1130/2019.2542(27).

Morel, J. - P., 1981. Céramique campanienne: les formes, Rome.

Oštrić, N., Jelaska V., Fuček, L., Prtoljan B., Korolija B., Gušić I., Marinčić S., Šparica M., Korbar, T. and Husinec, A., 2015. Osnovna geološka karta Republike Hrvatske mjerila 1:50 000 - list Hvari (Basic Geological Map of the Republic of Croatia scale 1:50.000 - sheet Hvar). Hrvatski geološki institut (Croatian Geological Survey), Zavod za geologiju (Department of Geology), Zagreb.

Papachristodoulou, C., Oikonomou, A., Ioannides, K. and Gravani, K., 2006. A study of ancient pottery by means of X-ray fluorescence spectroscopy, multivariate statistics and mineralogical analysis, Analytica Chmica Acta 573-574, pp. 347-353.

Papachristodoulou, C., Gravani, K., Oikonomou, A., and Ioannides, K., 2010. On the provenance and manufacture of red-slipped fine ware from ancient Cassope (NW Greece): evidence by X-ray analytical methods, Journal of Archaeological Science 37, pp. 2146-2154.

Parker, A. J., 1992. Ancient Shipwrecks of the Mediterranean and the Roman Provinces, BAR Inter. Ser. 580, Oxford.

Popović, S., 2010, Rezultati novih zaštitnih istraživanja u Starome Gradu na otoku Hvaru. In: Ivčević S. and Piteša A., (Eds.), Arheološka istraživanja na srednjem Jadranu, Zagreb - Split: Izdanja Hrvatskog arheološkog društva, pp. 137-149.

Popović, S. and Devlahović, A., 2018. New Answer to Old Problems. Revitalizing Questions about the Location of Pharos and its City Walls. In: Katsonopoulo, D., (Ed.) Proceedings of the fourth international conference on the archaeology of Paros and the Cyclades Paroikia, Paros, 11-14 June 2015, Paros IV. Paros and its colonies, Paros 2015, pp. 377-395.

Quinn, S. P., 2013, Ceramic Petrography. The Interpretation of Archaeological Pottery \& Related Artefacts in Thin Section, Oxford: Archaeopress.

Rotunno, T., Sabbatini, L., and Corrente, M., 1997. A provenance study of pottery from archaeological site near Canosa, Puglia (Italy), Archaeometry 39 (3), pp. 343-354.

Slapšak, B. and Kirigin, B., 2001. Pharos and its Chora. In: Atti del quarantesimo convegno di studi sulla Magna Grecia (Problemi della "Chora" Coloniale dall'Occidente al Mar Nero, Taranto): Taranto, Italy, Institut per la storia e l'archeologia della Magna Grecia, pp. 567591.

Šegvić, B., Šešelj, L., Slovence, D., Lugović, B. and Ferreiro Mählmann, R., 2012. Composition, Technology of Manufacture, and Circulation of Hellenistic Pottery from the 
Eastern Adriatic: A Case Study of Three Archaeological Sites along the Dalmatian Coast, Croatia, Geoarchaeology: An International Journal 27, pp. 53-87.

Šegvić, B., Ugarković, M., Süssenberger, A., Ferreiro Mählmann, R. and Moscariello, A., 2016. Compositional properties and provenance of Hellenistic pottery from the necropolis of Issa with evidences of the cross-Adriatic and Mediterranean-scale trade, Mediterranean Archaeology and Archaeometry, 16 (1), pp. 23-53.

Šešelj, L., 2009. Promonturium Diomedis: svetište na rtu Ploča i jadranska pomorska trgovina $u$ helenističkom razdoblju (PhD Thesis), University of Zadar.

Whitbread, I. K., 1996. Detection and interpretation of preferred orientation in Ceramic Thin sections, Proceedings of the $2^{\text {nd }}$ Symposium of the Hellenic Archaeometrical Society, pp. 413425 .

Yntema, D. G., 2001. Pre-Roman Valesio, Volume I: The pottery, Amsterdam.

Yntema, D. G., 2005. Conspectus Formarum of Apulian Grey Gloss wares, Amsterdam. 


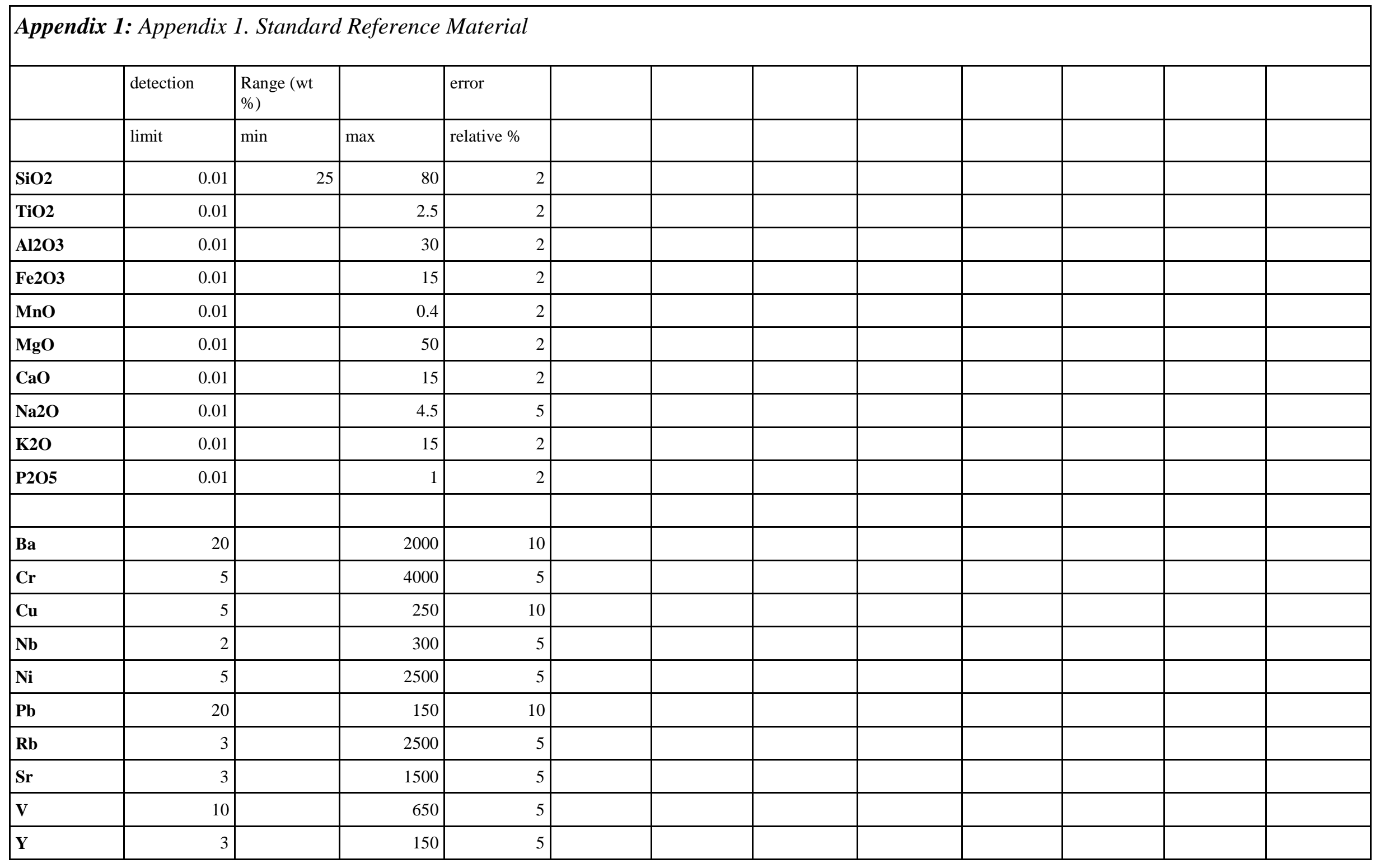




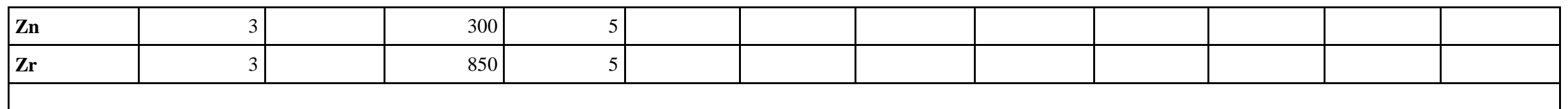

Appendix 2: clay reference sample

\begin{tabular}{|c|c|c|c|c|c|c|c|c|c|c|c|c|}
\hline RT (clay) & $\mathrm{SiO} 2$ & $\mathrm{TiO} 2$ & $\mathrm{Al} 2 \mathrm{O} 3$ & $\mathrm{Fe} 2 \mathrm{O} 3$ & $\mathrm{MnO}$ & $\mathrm{MgO}$ & $\mathrm{CaO}$ & $\mathrm{Na} 2 \mathrm{O}$ & $\mathrm{K} 2 \mathrm{O}$ & $\mathrm{P} 2 \mathrm{O} 5$ & & \\
\hline & wt $\%$ & wt $\%$ & wt $\%$ & wt $\%$ & wt $\%$ & wt $\%$ & wt $\%$ & wt $\%$ & wt $\%$ & wt $\%$ & & \\
\hline Mean $(n=4)$ & 60.61 & 0.66 & 16.3 & 5.59 & 0.08 & 3.55 & 8.69 & 1.53 & 3.43 & 0.1 & & \\
\hline SD & 0.35 & 0 & 0.05 & 0.01 & 0 & 0.01 & 0.03 & 0.19 & 0.02 & 0 & & \\
\hline RSD & 0.58 & 0 & 0.32 & 0.25 & 0 & 0.36 & 0.29 & 12.3 & 0.51 & 0 & & \\
\hline \multirow[t]{2}{*}{ RT (clay) } & $\mathrm{Ba}$ & $\mathrm{Cr}$ & $\mathrm{Cu}$ & $\mathrm{Nb}$ & $\mathrm{Ni}$ & $\mathrm{Pb}$ & $\mathrm{Rb}$ & $\mathrm{Sr}$ & V & Y & $\mathrm{Zn}$ & $\mathrm{Zr}$ \\
\hline & ppm & ppm & ppm & ppm & ppm & ppm & ppm & ppm & ppm & ppm & ppm & ppm \\
\hline Mean $(n=4)$ & 391.75 & 103.75 & 32.5 & 13.75 & 65.5 & 27.5 & 164.25 & 349.25 & 118 & 29.25 & 105.5 & 156.25 \\
\hline SD & 13.96 & 2.22 & 1.29 & 0.96 & 1.73 & 2.52 & 0.96 & 4.72 & 3.92 & 1.26 & 1 & 3.59 \\
\hline RSD & 3.56 & 2.14 & 3.97 & 6.96 & 2.64 & 9.15 & 0.58 & 1.35 & 3.32 & 4.3 & 0.95 & 2.3 \\
\hline
\end{tabular}

